UNIVERSIDADE DE SÃO PAULO

FACULDADE DE MEDICINA DE RIBEIRÃO PRETO

\title{
Expressão gênica de citocinas em cobaias resistentes a carrapatos Rhipicephalus sanguineus
}

Dissertação apresentada à Faculdade de Medicina de Ribeirão Preto, Universidade de São Paulo, para a obtenção do Grau de Mestrado em Imunologia Básica e Aplicada.

Aluna: Alessandra Mara Franzin

Orientador: Prof ${ }^{\mathrm{a}}$. Dr ${ }^{\mathrm{a}}$, Beatriz Rossetti Ferreira Co-orientador: $\operatorname{Prof}^{a}$. Dr ${ }^{a}$, Lucy M. Yamaushi Lioni

Ribeirão Preto - SP

2005 
FICHA CATALOGRÁFICA

\section{FRANZI N, Alessandra Mara}

Expressão gênica de citocinas em cobaias resistentes a carrapatos

Rhipicephalus sanguineus. Ribeirão Preto, 2004.

68 p. il. ; $29 \mathrm{~cm}$

Dissertação de Mestrado apresentada à Faculdade de Medicina de Ribeirão Preto / USP - Área: Imunologia Básica e Aplicada.

Orientador: Ferreira, Beatriz Rossetti.

Unitermos: 1. Rhipicephalus sanguineus, 2. Citocinas, 3. Cobaias, 4. mRNA, 5. Resistência 


\section{DEDICATÓRIA}

A minfra família .....

$\mathcal{A}$ porta da verdade estava aberta,

Mas só deixava passar

Meia pessoa de cada vez.

Assim não era possível atingir toda a verdade,

Porque a meia pessoa que entrava

Só trazia o perfil de meia verdade.

E sua segunda metade

Voltava igualmente com meio perfil.

$\mathcal{E}$ os meios perfis não coincidiam.

Arrebentaram a porta. Derrubaram a porta.

Chegaram ao lugar luminoso

Onde a verdade esplendia seus fogos.

Era dividida em metades

Diferentes uma das outras.

Chegou-se a discutir qual a metade mais bela.

Nenfuma das duas era totalmente bela.

E carecia optar. Cada um optou conforme

Seu capricho, sua ilusão, sua miopia.

(Carlos Drummond de Andrade) 


\section{Agradecimentos}

À Profa. Dra. Beatriz Rossetti Ferreira, por me guiar, de maneira tão sábia, nos meus primeiros passos rumo ao admirável mundo da Ciências e por me mostrar que seres vivos simples a primeira vista, como carrapatos, têm muito a nos ensinar. Terei sempre seus ensinamentos guardados como parte de mim.

À Profa. Dra. Lucy Megume Yamaushi Lioni, por me ensinar que a "Paciência Oriental", dentre outras, é a principal virtude a ser cultivada por todos nós, principalmente por mim. Não poderia deixar de agradecer por todas as vezes que você se dispôs a me auxiliar.

Ao Prof. Dr. João Santana da Silva, por me aceitar como estagiária em seu laboratório, pelos sábios conselhos que contribuíram para a realização deste trabalho e pela oportunidade de aprender e trabalhar em seu laboratório.

À Profa. Dra. Isabel F. K. de Miranda dos Santos, pelo auxílio e sugestões na realização deste trabalho e por me mostrar que para vencer as adversidades basta um pouco de perseverança.

Ao Prof. Dr. Matias P. J. Szabó e ao Prof. Dr. Gervásio Henrique Bechara, pesquisadores pioneiros das relações carrapatos/hospedeiro, por contribuírem com suas pesquisas para a realização deste trabalho.

Ao Prof. Dr José Alejandro Chabalgoity, pelo auxílio no delineamento dos primers e padronização das reações de PCR.

Ao Prof. Dr. Célio Lopes Silva por ceder seu laboratório para a realização da quantificação do RNA total obtido das amostras analisadas neste trabalho. 
À Profa. Dra. Mônica Magalhães Zini, por me ensinar que para entender Imunologia é preciso pensar que "tudo acontece ao mesmo tempo e agora".

Aos meus colegas de laboratório, pela amizade, respeito e paciência oferecidos a mim cotidianamente. À Daniela por ter a difícil missão de dividir o computador comigo, pelas conversas e pelos conselhos; à Wanessa por sua alegria brasiliense; à Claudia pelo carinho; à Karina, Lis e Marcos Valério, pela alegria e sensibilidade; ao Antônio, Lucinda e Carlo, pelos momentos de descontração.

À Karen, ao Gustavo e a Cristina, pela amizade e auxílio em momentos imprescindíveis à realização deste trabalho. Aos amigos Luciano e Marcelo, pelos momentos de alegria e as refeições descontraídas. À Anika e á Flávia, pelas palavras de carinho. Ao Fredy, pelos seus comentários silenciosos. À Daniele, pelos conselhos e a Pauline, por me lembrar que a graduação é a melhor época de nossas vidas. À Vanessa, pelos bons sentimentos.

À Ana Campanelli, por quem tenho grande admiração, agradeço pelos dias de sol que seu sorriso me trouxe em épocas difíceis. À Fabiana e Lísia, por me auxiliarem a entrar na pós-graduação e pelos momentos de festa. A Márcia Livonesi, pela compreensão e momentos de alegria.

Aos meus amigos Leandro, Luis, Mariângela, Luciana, Eduardo e Silvia. A felicidade reside em pequenos momentos que nos são preciosos. Agradeço a vocês por cada um deles.

À Ana Cristine por ser a nossa querida "Ana". Sem você, eu e os demais alunos da pós-graduação estaríamos lançados à própria sorte. À Rosângela, a 
Jesiane e á todos da CPG, que jamais nos deixam a deriva quando a burocracia da pós-graduação nos parece interminável.

Aos meus amigos Wander, Sávio, Julio, Cris, Lúcia e Edinelson, pela amizade, carinho, almoços agradáveis e a participação ativa neste trabalho e na pós-graduação.

Ao Sr Rinaldo, ao Sr Bibi, ao Sr Antônio e ao Sr Ângelo, pela prestatividade e disposição ao me auxiliaram na manutenção da colônia de carrapatos.

À Cristiane Milanezi, agradeço por seu auxílio neste trabalho e no bom andamento do laboratório.

À Isa e todos os meus amigos do laboratório do Dr. Célio Lopes, por me acolherem nos momentos de extrema necessidade, por seu auxílio e amizade.

Aos amigos do Departamento de Imunologia, pela amizade e respeito.

Aos meus amigos do Hospital das Clínicas, por me ensinarem que as amostras de material biológico representam seres humanos e devem ser examinadas com responsabilidade e respeito.

Ao Conselho Nacional de Desenvolvimento Científico e Tecnológico (CNPq), pela concessão da bolsa que possibilitou a realização deste trabalho. 
Queremos saber,

O que vão fazer

Com as novas invenções

Queremos notícia mais séria

Sobre a descoberta da antimatéria

e suas implicações

$\mathcal{N a}$ emancipação do fromem

Das grandes populações

Homens pobres das cidades

Das estepes dos sertões

Queremos saber,

Quando vamos ter

Raio laser mais barato

Queremos, de fato, um relato

Retrato mais sério do mistério da luz

Luz do disco voador

Pra iluminação do fromem

Tão carente, sofredor

Tão perdido na distância

$\mathcal{N a}$ morada do senfior

Queremos saber,

Queremos viver

Confiantes no futuro

Por isso se faz necessário prever

Qual o itinerário da ilusão

$\mathcal{A}$ ilusão do poder

Pois se foi permitido ao homem

Tantas coisas confecer

É melhor que todos saibam

$O$ que pode acontecer

Queremos saber,

queremos saber

Todos queremos saber.

Queremos saber

(Gilberto Gil) 
Expressão de mRNA de citocinas em cobaias resistentes a carrapatos

Rhipicephalus sanguineus

\section{ÍNDICE}

\section{RESUMO}

2. SUMMARY

3. INTRODUÇÃO

04

2.OBJETIVOS

3.2. Cobaias 23

3.3. Cães domésticos 23

3.4. Manutenção da colônia de carrapatos 25

3.5. Coleta de saliva de carrapatos 25

3.6. Dosagem de proteínas na saliva de carrapatos 26

$\begin{array}{ll}\text { 3.7. Infestação de cobaias com carrapatos } & 27\end{array}$

3.8. Inoculação de saliva de carrapatos em cobaias 28

3.9. Extração de RNA 29

3.10. Reação de RT-PCR 30

3.11. Análise da intensidade de expressão de mRNA

3.12. Análise estatística 
4.1.1. Efeito das infestações de carrapatos na expressão de mRNA de citocinas na pele de cobaias.

4.1.2. Efeito das infestações de carrapatos na expressão de mRNA de citocinas nos

$$
\text { linfonodos de cobaias. }
$$

4.1.3. Efeito da inoculação de saliva de carrapatos na expressão de mRNA de citocinas na pele de cobaias.

4.1.4. Efeito da inoculação de carrapatos na expressão de mRNA de citocinas nos linfonodos de cobaias.

5. DISCUSSÃO

6. CONCLUSÕES 


\section{RESUMO}

Carrapatos são artrópodes hematófagos de distribuição cosmopolita que parasitam vertebrados e transmitem uma grande variedade de agentes infecciosos para o homem e animais domésticos.

Cobaias, diferentemente de cães e camundongos, são capazes de desenvolver resistência a carrapatos Rhipicephalus sanguineus após sucessivas infestações. Ao comparar o tipo de resposta imune desenvolvida por cobaias e cães frente a carrapatos observou-se que cobaias re-infestadas desenvolvem uma pequena reação de hipersensibilidade imediata e uma forte reação de hipersensibilidade tardia à inoculação cutânea com antígenos de carrapatos. Já em cães e camundongos, é notada somente uma forte reação de hipersensibilidade imediata. Também foi verificado que células dos linfonodos de cobaias infestadas três vezes com carrapatos (resistentes) proliferam intensamente na presença de saliva de carrapatos, diferentemente do que ocorre com células de cães e camundongos re-infestados (suscetíveis) que não proliferam. Esses achados sugerem o envolvimento de um padrão Th1 de resposta imune na aquisição de resistência, no entanto essa hipótese ainda não foi confirmada.

Assim sendo, no atual trabalho procurou-se verificar a expressão de mRNA de citocinas na pele e linfonodos de cobaias infestadas e re-infestadas com carrapatos. Para tal foram delineados primers e padronizadas reações de PCR para detectar a expressão de mensagem das citocinas IL-12p40, IFN- $\gamma$ e TNF- $\alpha$, 
pertencentes a um padrão Th1, e IL-4, IL-5, IL-10 e TGF- $\beta$, pertencentes a um padrão Th2 de resposta imune.

Os resultados obtidos demonstraram que cobaias sucessivamente infestadas apresentaram um aumento significativo na intensidade de mensagem para IL-12p40 nos linfonodos, tanto comparado com animais uma vez infestados (aumento de 2,6 vezes), quanto comparado com os controles (aumento de 13 vezes). Embora a análise estatística não tenha apontado uma diferença significativa houve elevação consistente na intensidade de mRNA para IFN- $\gamma$ nos linfonodos de cobaias re-infestadas comparadas às infestadas apenas uma vez (aumento de 2,4 vezes). Também foi observado um aumento significativo na intensidade da mensagem para IL-5 nos linfonodos de cobaias infestadas uma vez quando comparadas aos controles (aumento de 5 vezes). Não foi detectada expressão de mensagem para IL-4 e IL-10 nas amostras analisadas. Já a expressão de mensagem para TGF- $\beta$ foi observada em todos os animais (experimentais ou controles), sugerindo que essa citocina possa ter uma expressão constitutiva em cobaias.

Tomados em conjunto, os resultados sugerem o envolvimento predominante de um perfil de citocinas de padrão Th1 na aquisição de resistência em cobaias a carrapatos. Nossos resultados poderão auxiliar o desenvolvimento de novas abordagens para o controle de carrapatos, como, por exemplo, sugerir adjuvantes mais adequados a serem utilizados em vacinas anti-carrapatos. O conhecimento gerado não se restringe à indução de proteção contra carrapatos como também a possibilidade de aumentar a resistência de hospedeiros a patógenos transmitidos por carrapatos que poderiam ser controlados por uma resposta tipo Th1. 


\section{SUMMARY}

Ticks are hematophagous arthropods of cosmopolitan distribution and are significant vectors of several diseases for humans and animals.

Guinea pigs, unlike dogs and mice, develop resistance to Rhipicephalus sanguineus ticks after successive infestations. When the immune reaction between tick-infested guinea pigs and dogs/mice are compared, guinea pigs develop both immediate and strong delayed type hypersensitivity reactions while dogs and mice develop only a strong immediate reaction. Additionally was shown that lymph node cells from tick-infested guinea pigs (resistant hosts) proliferate intensely when cultured with tick saliva, differently to what is observed with cells from tick-infested dogs and mice (susceptible hosts). These findings propose the contribution of a Th1 cytokine pattern on the acquired immune response to ticks; however this hypothesis still has to be tested.

This being so, in this study we investigated the expression profile of genes coding for selected cytokines on $R$. sanguineus infested guinea-pigs. Messenger RNA for IL-12-p40, IFN- $\gamma$ and TNF- $\alpha$ (Th1 cytokine pattern) and IL-4, IL-5, IL-10 and TGF- $\beta$ (Th1 cytokine pattern) was measured in skin and lymph nodes biopsies from tick-infested guinea pigs.

Our results demonstrated that repeatedly tick-infested guinea pigs presented a significant increase on the intensity of message for IL-12p40 in the lymph nodes compared to both, one time tick-infested guinea pigs (raise of 2.6 times) or controls (raise of 13 times). Although the statistical analysis did not point out differences, there was a consistent increase on the mRNA intensity for IFN- $\gamma$ on 
the lymph nodes from re-infested guinea pigs compared to one time tick-infested animals (raise of 2.4 times). In addition, a significant enhance on the intensity of message for IL-5 on the lymph nodes from one time tick-infested guinea pigs compared to the controls (raise of 5 times). No message for IL-4 and IL-10 was detected on the analyzed tissues. In contrast, TGF- $\beta$ was detected on tissues collected from all animals (experimental or controls), suggesting a spontaneous production of this cytokine in guinea pigs.

Taken together, these data suggest that a $\mathrm{T}$ helper 1-type pattern of cytokine production might be associated with the resistance expressed by guineapigs to ticks. Moreover, our results can provide new approaches to control ticks, i.e. suggest adjuvants to be added to anti-tick vaccines that preferably induce a Th1-type of response. 


\section{INTRODUÇÃO}

Carrapatos são artrópodes hematófagos de distribuição cosmopolita que parasitam vertebrados e transmitem uma grande variedade de agentes infecciosos para o homem e para os animais domésticos. Atualmente as perdas econômicas causadas por este ácaro são imensas; e relacionam-se, principalmente, ao seu parasitismo em bovinos. A cadeia nacional da pecuária bovina possui o maior rebanho comercial do mundo, gera mais de 7 milhões de empregos diretos, contribuindo com cerca de $10 \%$ do Produto Interno Bruto e movimenta exportações da ordem de US\$1,5 bilhões/ano (ANON., 1997, BLISKA, 1997).

A intensa infestação com o carrapato do boi, Boophilus microplus, compromete a produtividade de rebanhos e a competitividade de seus produtos. A Tristeza Parasitária Bovina, por exemplo, é um complexo de doenças causadas por protozoários do gênero Babesia (babesiose) e rickéttsias do gênero Anaplasma (anaplasmose), transmitidos por essa espécie de carrapato, e causa aumento nos índices de mortalidade e morbidade, com significativa redução na produção de carne e leite, aborto e menor fertilidade dos animais infestados.

Estima-se que $80 \%$ do rebanho bovino mundial esteja infestado por carrapatos, o que, de acordo com a "Food and Agriculture Organization" (FAO), (1995) origina um custo de 7,5 bilhões de dólares anuais. Não existem dados recentes no Brasil, mas, quando da última computação dos prejuízos causados pelo carrapato, feita em 1987 pelo Ministério da Agricultura e do Abastecimento, estes excediam US\$ 1 bilhão por ano (ANÔNIMO, 1983). 
Os prejuízos citados advêm, tanto da conseqüência direta do hematofagismo e das lesões cutâneas, como indiretamente, pela transmissão de agentes infecciosos. Carrapatos também infestam outros animais domésticos e o homem. Dentre as doenças veiculadas por carrapatos, de importância veterinária no Brasil temos a babesiose, anaplasmose e erliquiose; já de importância médica , temos a doença de Lyme, febre maculosa, febre hemorrágica do Congo e da Criméia, encefalites arbovíricas e erliquiose. A doença de Lyme é a doença humana transmitida por carrapatos que mais tem preocupado as autoridades sanitárias dos EUA (CENTERS FOR DISEASE CONTROL AND PREVENTION, 2002). Seu agente etiológico é a espiroqueta Borrelia burgdorferi, transmitida por carrapatos do gênero Ixodes (SIGAL, 1997). No Brasil, a febre maculosa (agente etiológico Rickettisia rickettsii) tem sido a grande preocupação das autoridades sanitárias, principalmente na região de Campinas (interior do estado de São Paulo) onde se concentrou nos últimos seis anos (1996-2002) com 79,1\% dos casos de febre maculosa notificados em todo o estado (Folha de São Paulo, 2003). Casos de erliquiose granulocítica (agente etiológico Ehrlichia equi) também têm sido cada vez mais freqüentes.

O controle de ácaros vem sendo feito com o emprego de carrapaticidas que, em sua maioria, são substâncias tóxicas (organoclorados, organofosforados, carbamatos, amitraz, piretróides sintéticos e ivermectina) que matam os carrapatos de forma direta. O uso destas substâncias é crescentemente oneroso e vem sendo feito de forma abusiva (TATCHELL, 1987), acarretando problemas como o surgimento de linhagens de carrapatos resistentes aos carrapaticidas e contaminação do meio ambiente (ELVIN \& KEMP, 1994). 
Procurando reduzir infestações por carrapatos, criadores de bovinos têm realizado uma conduta de manejo reprodutivo, buscando um rebanho mais resistente a carrapatos. Observando que o gado zebuíno (Bos indicus) é menos acometido por carrapatos que o gado europeu (Bos taurus) realizaram-se cruzamentos no sentido de obter bovinos mais resistentes. Desses cruzamentos, entretanto, resultaram freqüentemente perdas de características desejáveis, como por exemplo, a alta produtividade de leite do gado europeu. Por esses motivos têm-se buscado formas alternativas de controlar esses ácaros. Para tal, é necessário compreender melhor a interação dos carrapatos com seus hospedeiros, de forma a poder interferir desestabilizando a relação.

Desde o século passado, vem sendo observado que diferentes hospedeiros desenvolvem um grau variado de resistência a carrapatos após infestações sucessivas (BROWN, 1988a). Esse grau variado de resistência foi determinado observando queda na performance alimentar-reprodutiva dos ácaros durante o parasitismo. Notou-se também a participação de uma reação inflamatória modulada e complementada por uma resposta imune presente no local de fixação dos carrapatos. Tanto a reação inflamatória como a imune foram modeladas ao longo da evolução da relação entre carrapatos e seus hospedeiros.

O mecanismo desencadeador de resistência a ácaros ainda não está elucidado, havendo uma compreensão incompleta e muitas vezes especulativa sobre alguns eventos envolvidos na relação carrapato-hospedeiro. Características individuais e raciais dos animais, tais como a quantidade de glândulas sebáceas, espessura da pele, densidade da pelagem e fatores genéticos; podem colaborar com a resistência inata a carrapatos. TRAGER (1939) foi um dos primeiros 
pesquisadores que sugeriu a hipótese da participação da imunidade adquirida na resposta aos ácaros. No seu trabalho se demonstrou que cobaias, embora susceptíveis a uma primeira infestação com carrapatos Dermacentor andersoni, numa segunda infestação demonstravam resistência. Além disso, uma resistência parcial também pôde ser transferida passivamente pelo soro para animais que não haviam sido previamente expostos a carrapatos.

Nesse estudo ainda, foi observada a presença de reação inflamatória muito discreta no local de fixação dos carrapatos durante a primeira infestação. Já num segundo contato, verificou-se uma reação cutânea exacerbada, caracterizada por edema e intenso infiltrado celular (TRAGER, 1939). Diversos estudos têm demonstrado a participação de células como linfócitos, basófilos, eosinófilos (ALLEN, 1973; BROSSARD et al., 1982; SZABÓ \& BECHARA, 1999), mastócitos (MATSUDA et al., 1985) e células de Langerhans (ALLEN, 1979; NITHIUTHAI \& ALLEN, 1984a; 1984 e 1985) no infiltrado celular presente no sítio de alimentação de diversas espécies de carrapatos.

Mastócitos e basófilos são células desgranuladoras de histamina e serotonina, as quais inibem a salivação e ingurgitamento desses artrópodes (PAINE et al., 1983). Essas substâncias induzem vasodilatação e aumento da permeabilidade vascular as quais levam ao acúmulo de componentes do sistema complemento, imunoglobulinas e leucócitos. O edema formado pode ainda reduzir a disponibilidade de nutrientes no local de fixação, prejudicando a alimentação dos carrapatos (RIBEIRO, 1989). Outros mediadores farmacológicos como leucotrienos e prostaglandinas também podem interferir prejudicando a salivação e alimentação dos carrapatos (KEMP \& BOURNE, 1980; PAINE et al., 1983). 
A participação de populações e subpopulações de linfócitos na resposta imune a carrapatos é pouco caracterizada. Relatos apontam tanto para a participação de linfócitos $T$ como $B$ na imunidade a carrapatos, sugerindo envolvimento da resposta imune celular e humoral. O papel da resposta imune celular foi apontado em experimentos que mostraram que células do linfonodo e do exsudato peritonial de animais resistentes, ao serem transferidas, eram capazes de conferir resistência a animais não sensibilizados com carrapatos (WIKEL \& ALLEN, 1976; BROWN \& ASKENASE, 1981; ASKENASE et al., 1982). Ao se administrar ciclosporina A, uma substância imunossupressora que atua em linfócitos $T$ reduzindo a produção de IL-2, impediu-se o desenvolvimento de resistência em coelhos frente a carrapatos Ixodes ricinus (GIRARDIN \& BROSSARD, 1989); reafirmando o papel dessas células na aquisição de resistência a carrapatos.

Embora diversos trabalhos demonstrem que animais infestados com carrapatos produzam uma grande quantidade de anticorpos anticarrapatos, seu papel na proteção contra ácaros é pouco definido. O fato do soro de animais infestados reconhecer antígenos de carrapatos não significa necessariamente que esses anticorpos possuam papel fundamental na aquisição de resistência ao ectoparasita (WIKEL, 1996; SZABÓ et al., 2003). Apesar de alguns estudos mostrarem a possibilidade de se transferir resistência parcial a carrapatos através da transferência de soro de animais resistentes para "naives" (TRAGER, 1939; BROWN \& ASKENASE,1981), outros estudos têm demonstrado que, mesmo diante de uma grande produção de anticorpos a diversos tecidos de carrapatos, 
esses anticopos não são capazes de conferir resistência (JITTAPALAPONG et al., 2000).

Em termos de resistência e suscetibilidade a diversos patógenos, foi observado que a conseqüência do parasitismo pode ser determinada pelo padrão de resposta envolvendo subclasses de células $T$ helper $\mathrm{CD}^{+}$(SHER \& COFFMAN, 1992; KOBAYASHI et al., 2001). Neste contexto, foi determinado que células Th1 produzem IFN- $\gamma$, enquanto que células Th2 produzem IL-4, IL-13, IL-5 e IL-10; e que o padrão de citocinas produzido pode resultar numa resposta imune efetora em particular (MOSMANN \& COFFMAN, 1989; MOSMANN \& SAD, 1996; KOBAYASHI et al., 2001).

Citocinas associadas a células Th1 estão envolvidas na ativação de macrófagos, assim como na reação de hipersensibilidade do tipo tardia (DTH). Por outro lado, citocinas produzidas por células Th2 elevam o número de mastócitos e eosinófilos e estimulam a produção de anticorpos. Além disso, produtos de células Th1 e Th2 podem regular negativamente a produção e ou a atividade um do outro (MOSMANN \& MOORE, 1991; LYNCH et al., 2003). Sob esse prisma, a resistência ou suscetibilidade à infestação com carrapatos talvez possa ser explicada pela modulação da rede de citocinas.

Embora algumas espécies hospedeiras venham a desenvolver mecanismos de resistência contra carrapatos, outros falham em adquiri-lo. Essa falha na elaboração de imunidade efetivamente protetora pode ser vista por dois ângulos. O primeiro seria relativo ao mecanismo de escape do ectoparasita, o qual o torna capaz de modular a resposta de algumas espécies de hospedeiros, de forma a convergir para uma resposta ineficaz (WALKER et al., 1985). O segundo seria 
relativo à capacidade de algumas espécies hospedeiras desenvolverem resistência a essa modulação, tornando-as refratárias a carrapatos. Essa visão bimodal dá margem ao questionamento sobre quais seriam as "ferramentas" utilizadas pelos carrapatos para permanecer tempo suficiente sobre seus hospedeiros para obtenção de uma alimentação adequada. A resposta mais provável poderia encontrar-se na saliva produzida por carrapatos durante o ato de hematofagia.

Sabe-se que, enquanto os carrapatos se alimentam (2 a 15 dias, variando de acordo com o estágio e a espécie de carrapato), são inoculados cerca de 500 $\mu \mathrm{L}$ de saliva em um intervalo de $96 \mathrm{~h}$ (BALASHOV, 1972). O trauma mecânico causado pela fixação acompanhado da inoculação de saliva elicitam resposta inflamatória/ imunológica nos hospedeiros caracterizada por vasodilatação, formação de edema, migração celular e reparo do tecido. Tais eventos podem prejudicar o repasto sanguíneo dos ácaros (RIBEIRO et al., 1985).

Atualmente, são conhecidas inúmeras substâncias presentes na saliva de diferentes espécies de carrapatos com várias atividades farmacológicas relevantes. Um exemplo é a saliva de carrapatos Ixodes, a qual contém atividade anti-hemostática, antiinflamatória, inibidora da atividade da bradicinina, de anafilatoxinas e desativadora de neutrófilos (RIBEIRO et al., 1985; 1990; RIBEIRO \& SPIELMAN, 1986). Um estudo com extrato de glândulas salivares de carrapatos R. sanguineus mostrou que esse extrato possui atividade anti-histamínica (CHINERY \& AYITEY-SMITH, 1977). Através de estudo do transcriptoma de glândulas salivares de carrapatos $R$. sanguineus, nosso grupo identificou três 
genes diferentes codificadores de proteínas ligantes de serotonina e histamina (manuscrito em redação).

Extrato de glândulas salivares, assim como a saliva de I. ricinus, interfere na ação citotóxica das células NK tornando-as menos eficientes na sua atividade citotóxica (KOPECKY \& KUTHEJLOVA, 1998; NUTTALL et al., 2000; KUBES et al., 2002). Também foi observada a capacidade de bloquear a via alternativa do sistema complemento (RIBEIRO, 1987; LAWRIE et al., 1999; VALENZUELA et al., 2000) e de inibir a proliferação de linfócitos frente a mitógenos in vitro (RIBEIRO et al., 1985; MEJRI et al., 2002; FERREIRA et al., 2003).

De forma interessante, o extrato de glândulas salivares de carrapatos $D$. andersoni inibiu a resposta proliferativa de células $\mathrm{T}$ de camundongos e bovinos não infestados estimulados com concanavalina-A (Con-A), enquanto que a resposta linfoproliferativa de células B frente a lipopolissacarídeo (LPS) não foi alterada (RAMACHANDRA \& WIKEL, 1992; 1995). Esse mesmo extrato suprimiu a produção de citocinas tais como IL-1, TNF- $\alpha$, IFN- $\gamma$ por macrófagos, IL-2 por linfócitos e, ainda, reduziu a expressão de moléculas de adesão, tais como LFA-1 e VLA-4 em linfócitos (RAMACHANDRA \& WIKEL, 1992; MACALUSO \& WIKEL, 2001).

Foi descrito também que a saliva de carrapatos $R$ appendiculatus contém moléculas ligantes de imunoglobulina G, que, possivelmente, auxiliem os ectoparasitas a eliminarem anticorpos ingeridos junto com o repasto sanguíneo (WANG \& NUTTALL, 1999). É importante salientar que a saliva também é via de descarte para o excesso de líquidos e íons ingeridos do hospedeiro, de forma a concentrar nutrientes para futura oviposição (KAUFMAN, 1989). 
$\mathrm{Na}$ tentativa de encontrar fatores presentes na saliva de carrapatos envolvidos na modulação da resposta do hospedeiro foi identificada uma proteína presente nas glândulas salivares de carrapatos I. scapularis a qual se liga a IL-2 solúvel, secretada por linfócitos T ativados in vitro (GILLESPIE et al., 2001). Essa capacidade de seqüestrar IL-2 é extremamente relevante, pois muitas células do sistema imune, incluindo células B, macrófagos, células NK e células dendríticas, possuem receptores e podem ser ativadas por essa citocina (GILLESPIE et al., 2000; FUKAO, 2000).

Estudos utilizando extrato de glândulas salivares e saliva de $D$. andersoni identificaram uma proteína de aproximadamente 36 kDa, a qual é responsável pela supressão de células T (BERGMAN et al., 1995; BERGMAN et al., 1998). Cabe, no entanto, ressaltar que, até o momento, nenhuma molécula imunossupressora procedente de saliva de carrapatos foi completamente caracterizada.

Embora não tão importante economicamente quanto o carrapato de bovinos B. microplus nos países do Cone Sul e Austrália, o carrapato R. sanguineus desperta interesse por ser a espécie de maior disseminação mundial na atualidade, provavelmente pela ampla distribuição de seu hospedeiro, o cão doméstico (PEGRAM, 1987). Essa espécie de carrapato pode residir em ambiente doméstico, e chega a atingir níveis insuportáveis em muito pouco tempo, dado que seu ciclo biológico pode ser completado em dois meses, e cada teleógena ovipõe cerca de 3000 ovos. Como cada estágio pode persistir por vários meses sem se alimentar, a presença dos carrapatos pode perdurar muito tempo depois que o cão foi removido. O R. sanguineus é vetor de diversos patógenos de importância para 
os caninos, incluindo os agentes da babesiose, haemobartonelose, hepatozoonose e erliquiose. A participação do carrapato na transmissão de outros agentes infecciosos, tanto para animais como para humanos, é ainda motivo de pesquisa (PARKER E WILSON, 1979; STEPHEN E ACHYUTHARAO, 1980; PETER et al., 1984; SIMPSON et al., 1991; MUMCUOGLU et al., 1993).

Do ponto de vista científico, a interação de carrapatos $R$. sanguineushospedeiros é particularmente interessante, sendo que o hospedeiro natural, o cão doméstico, não desenvolve resistência, mesmo após diversas infestações (THEIS \& BUDWISER, 1974; SZABÓ et al., 1995). Parecem serem notáveis os mecanismos de evasão deste carrapato frente aos processos imunológicos do cão. Por outro lado, roedores de laboratório, como cobaias, desenvolvem uma forte resistência a essa espécie de carrapatos após a primeira infestação (CHABAUD,1950; GARIN e GRABAREV, 1972; SZABÓ et al., 1995).

Buscando possíveis explicações a respeito do fato de carrapatos poderem alimentar-se sem induzir resistência em cães, nosso laboratório vem pesquisando o efeito da saliva de carrapatos $R$. sanguineus na indução e expressão da resposta imune. Como existe pouca disponibilidade de reagentes para o estudo dos mecanismos envolvidos na resposta imune de cães a carrapatos, utilizou-se um modelo envolvendo animais de laboratório que reproduzisse uma situação similar à que ocorre em cães. Nesse sentido, verificou-se que camundongos de diversas linhagens, similarmente a cães, não desenvolvem resistência a carrapatos $R$. sanguineus, nem mesmo após quatro infestações consecutivas (FERREIRA \& SILVA, 1998). Camundongos, então, foram utilizados como modelo experimental para pesquisar a relação carrapato-hospedeiro susceptível. 
Foi demonstrado que a saliva de carrapatos $R$. sanguineus: (1) suprime de forma dose-resposta à proliferação de células de camundongos normais estimuladas in vitro com Con-A ou a proliferação celular antígeno-específica; (2) não altera a capacidade dos macrófagos apresentarem antígenos a linfócitos previamente sensibilizados; (3) inibe a capacidade microbicida (dependente de óxido nítrico) de macrófagos estimulados com IFN- $\gamma$ e (4) reduz a produção de IFN- $\gamma$ e aumenta a produção de IL-10 por células do baço de camundongos cocultivados com Trypanosoma cruzi (FERREIRA \& SILVA, 1998).

Quanto ao perfil de citocinas sintetizado por camundongos infestados sucessivamente com carrapatos $R$. sanguineus, observou-se primeiramente uma proliferação celular inibida quando suas células eram estimuladas in vitro com Con-A, e que essa supressão estava restrita a células obtidas dos linfonodos situados próximos ao sítio de fixação dos carrapatos, sugerindo uma regionalização da resposta a carrapatos. As células dos linfonodos regionais de camundongos re-infestados (no sexto dia de infestação) sintetizaram reduzidos níveis de citocinas associadas com linfócitos do tipo Th1, ou seja, IL-2, IFN- $\gamma$ e IL12. Por outro lado, produziram elevados níveis de citocinas associados com linfócitos Th2, ou seja, IL-4, IL-10 e TGF- $\beta$ (FERREIRA \& SILVA, 1999).

A resposta Th2 induzida pela infestação com carrapatos $R$. sanguineus pode ser vantajosa para os ácaros, considerando que citocinas associadas a um padrão Th2 têm sido atribuídas a respostas antiinflamatórias (ABBAS et al., 1996), e a inflamação no local de fixação dos carrapatos poderia prejudicar o ingurgitamento dos mesmos (RIBEIRO et al., 1985). 
Como previamente comentado, cobaias, diferentemente de cães e camundongos, desenvolvem resistência a carrapatos após sucessivas infestações (STEEVES \& ALLEN, 1990; SZABÓ et al., 1995). Comparando-se a reação histopatológica entre cobaias e cães após sucessivas infestações, verificou-se que cães apresentam um infiltrado celular composto principalmente por neutrófilos e mononucleares, enquanto que cobaias mostram um acúmulo de mononucleares e um aumento no número de eosinófilos e basófilos (SZABÓ \& BECHARA, 1999).

Quanto ao tipo de reação de hipersensibilidade cutânea induzida no local de fixação dos carrapatos $R$. sanguineus em hospedeiros infestados, observou-se uma forte reação de hipersensibilidade imediata em cães e camundongos, enquanto que cobaias desenvolveram uma pequena reação imediata e forte reação de hipersensibilidade tardia (SZABÓ et al, 1995 e FERREIRA et al., 2003). O desenvolvimento de reação tardia num teste de hipersensibilidade cutâneo a antígenos de carrapatos em cobaias infestadas com carrapatos sugere 0 envolvimento do braço celular (Th1) da resposta imune no processo de aquisição de resistência a esse ectoparasita.

Uma melhor caracterização do tipo de resposta a carrapatos desenvolvida por camundongos, cães e cobaias poderá vir a sugerir novas formas de controle desses ectoparasitas Com esse intuito, foram cultivadas células dos linfonodos de cobaias infestadas três vezes com carrapatos, portanto resistentes, na presença de saliva de carrapatos. Os resultados mostraram que houve reconhecimento antigênico, resultando em alta proliferação celular (14 vezes maior que células de cobaias não infestadas), sugerindo que antígenos inoculados numa infestação com carrapatos podem induzir resposta imune celular específica e conduzir ao 
desenvolvimento de resistência. Ao contrário, células de camundongos e cães reinfestados com carrapatos não responderam à secreção salivar de carrapatos, e, dessa forma, permaneceram suscetíveis (FERREIRA et al., 2003).

Outro achado que vem a contribuir com a hipótese de que a saliva atua de forma diferente em cobaias foi obtido a partir de uma cultura de células dos linfonodos de camundongos e cobaias re-infestados com carrapatos na presença de Con-A. Enquanto células de camundongos re-infestados mostraram uma redução de $82,4 \%$ no índice de estimulação, comparado a controles não infestados; células de cobaias re-infestadas proliferaram normalmente após a estimulação com Con-A (FERREIRA et al., 2003). Esses resultados apontam para uma imunossupressão como resultado da ação da saliva de carrapatos sobre células de linfonodos de cães e camundongos. O mesmo não ocorrendo para células de linfonodos de cobaias infestadas sucessivamente, sugerindo que esses hospedeiros demonstram diferenças significativas na elaboração da resposta imune contra carrapatos.

Embora tais estudos tenham demonstrado que há participação efetiva de imunidade mediada por células na resposta protetora contra carrapatos e que camundongos (hospedeiros suscetíveis) desenvolvem um padrão Th2 de citocinas, não se pode afirmar que a resistência adquirida por cobaias seja conferida pela predominância de um padrão Th1 de resposta imune.

Dessa forma, o presente trabalho vem a contribuir para o esclarecimento do perfil de citocinas envolvidas na aquisição de resistência. Os resultados obtidos poderão ser empregados no desenvolvimento de novas estratégias para o controle de carrapatos. 


\section{OBJETIVOS}

Baseando-se nos fatos expostos, tivemos como objetivo neste estudo:

1. Delinear e padronizar as reações de polimerase em cadeia precedidas de transcrição (RT-PCR) para a determinação da expressão de mensagem para IL-4, IL-5, IL-10, TGF- $\beta$, TNF- $\alpha$, IFN- $\gamma$ e IL-12p40 de cobaias.

2. Analisar a intensidade da expressão de mRNA para as citocinas na pele e linfonodos de cobaias após uma e sucessivas infestações com carrapatos $R$. sanguineus.

3. Verificar a intensidade da expressão de mensagem para citocinas na pele e linfonodos de cobaias após sucessivas inoculações intradérmicas de saliva. 


\section{MATERIAL E MÉTODOS}

\section{Animais experimentais}

\subsection{Cobaias}

Para a realização da parte experimental foram utilizadas 40 cobaias albinas fêmeas com idades entre 3 e 4 meses. Essas cobaias foram obtidas no Biotério Central da FMRP-USP e mantidas no Biotério do Depto. de Bioquímica e Imunologia da FMRP-USP.

\subsection{Cães domésticos}

Nos experimentos de infestações para coleta de saliva de carrapatos foram utilizados 10 cães sem raça definida, de ambos os sexos, com idades variadas. Os cães foram obtidos e mantidos no Biotério Central da FMRP-USP. Dois dias antes das infestações com carrapatos os cães eram banhados e transferidos para um canil (dois animais/ canil) para as infestações.

\section{Manutenção da colônia de carrapatos}

A colônia de carrapatos $R$. sanguineus já está implantada em nosso laboratório. A manutenção foi realizada segundo BECHARA et al., (1995). Para tal, carrapatos fêmeas ingurgitadas foram colocadas para oviposição em recipientes plásticos. Após um período de 10 dias, completada a oviposição, as fêmeas foram retiradas e desprezadas. Aguardou-se a eclosão completa dos ovos (18-25 dias). Para a obtenção de todos os estágios de vida do carrapato, larvas e 
ninfas não ingurgitadas foram alimentadas em cobaias nunca antes infestadas, dentro de câmaras de alimentação fixadas sobre o dorso tricotomizado dos animais com uma cola atóxica (Britannia Adhesives P4104 Latex, UK). As câmaras de alimentação foram confeccionadas com cilindros plásticos com 2,5 $\mathrm{cm}$ de largura por $3 \mathrm{~cm}$ de profundidade sendo colados a uma peça de borracha fina de 1-2 $\mathrm{mm}$ de espessura cortada em formato de disco (com diâmetro de 7 $\mathrm{cm}$ ), contendo uma janela central com diâmetro equivalente ao do cilindro utilizado. Sob o disco de borracha, colou-se um tecido de algodão de dimensão e formato iguais ao disco, tornando a superfície do disco adequada para ser colada na pele dos animais. A câmara de alimentação foi fechada por uma tampa de encaixe perfurada.

A colônia de carrapatos foi mantida numa estufa incubadora para B.O.D (demanda bioquímica de oxigênio) umidificada, a uma temperatura de $28^{\circ} \mathrm{C}$. Os carrapatos mantiveram os parâmetros normais de ciclo biológico (SRIVASTAVA \& VARMA,1964; FREITAS et al., 1982; BECHARA et al., 1995).

\section{Coleta de saliva de carrapatos}

Para a coleta de saliva de carrapatos foram realizadas infestações com duas câmaras de alimentação por cão, onde 140 carrapatos (machos e fêmeas, proporção 1:1) foram liberados por câmara. A saliva foi coletada segundo a técnica de BECHARA et al. (1988), adaptada para carrapatos $R$ sanguineus. Resumidamente, carrapatos fêmeas ingurgitados, provindos da colônia e alimentados em cães por 7 dias, foram recolhidos, limpos com solução de tampão fosfato bicarbonato $0,1 \mathrm{M} \quad \mathrm{pH} \quad 7,2$ (PBS) e em seguida inoculados 
subcuticularmente na hemocele com 10-20 $\mu \mathrm{L}$ de uma solução de dopamina a 0,2\% diluída em PBS, com o auxílio de uma agulha 12,7 x 0,33 mm (Becton Dickinson, $\mathrm{NJ}$ ). Os ácaros foram então fixados a uma fita crepe e mantidos em câmara úmida, com temperatura superior a $25^{\circ} \mathrm{C}$. A coleta de secreção salivar do hipostômio das carrapatas foi realizada com pipeta automática, sendo a saliva mantida em tubo tipo "eppendorf" fechado sob banho de gelo. Após a coleta, a saliva foi filtrada através de uma membrana com poro de 0,22 $\mu \mathrm{m}$ (Costar-Corning Incorporated, NY) e mantida a $-20^{\circ} \mathrm{C}$ até o momento do uso. Os experimentos de inoculações intradérmicas foram realizados utilizando pool de salivas obtidas em diferentes dias, compreendendo material de, no mínimo, 150 carrapatas.

\section{Dosagem de proteína presente na saliva}

A dosagem da proteína do pool de saliva de carrapatos utilizado nos ensaios de inoculação intradérmica apresentou uma concentração de $46,44 \mu \mathrm{g} / \mathrm{ml}$ de proteína. A concentração de proteína foi determinada com uso do Bicinchoninic Acid Kit for Protein Determination (Sigma, MI). A leitura foi realizada em leitor de microplacas (EMAX, Molecular Devices Corporation, Sunnyvale, CA).

\section{Infestação de cobaias com carrapatos}

Dez cobaias foram infestadas uma ou três vezes com carrapatos ( $n=5 /$ grupo) de acordo com metodologia previamente descrita (SZABÓ et al., 1999; 2003 e FERREIRA et al., 2003). Dois grupos controle (cinco cobaias em cada) foram realizados em paralelo com os experimentais, e consistiam de cobaias com câmaras de alimentação coladas ao dorso, porém sem carrapatos. 
Resumidamente, as infestações foram conduzidas de forma controlada utilizando câmaras de alimentação fixadas com cola atóxica (Britannia Adhesives P4104 Latex, UK) ao dorso dos animais tricotomizados. As câmaras de alimentação foram confeccionadas utilizando um tubo tipo "criovial" (CorningCostar) com $0,9 \mathrm{~cm}$ de diâmetro e $1,5 \mathrm{~cm}$ de altura com o fundo cortado e colado a uma peça de borracha fina de 1-2 $\mathrm{mm}$ de espessura cortada em formato de disco (com diâmetro de 2,5 cm), contendo uma janela central com diâmetro equivalente ao do tubo utilizado. A borracha foi aderida a um tecido de algodão o qual foi colado à pele do animal. Na janela central da câmara de alimentação, foram liberados 6 casais de carrapatos, sendo o tubo fechado. As infestações foram monitoradas diariamente, observando-se a fixação e o desenvolvimento dos carrapatos.

Para o grupo três vezes infestado durante a primeira e segunda infestação as câmaras foram mantidas nos animais por até 14 dias, enquanto que na terceira os animais foram sacrificados 24 h após a fixação dos ácaros. Nos animais controle, obedeceu-se ao mesmo procedimento quanto à colocação das câmaras de alimentação (sem os carrapatos) e os animais foram sacrificados juntamente com os infestados. O intervalo entre infestações foi de 30 dias. Já o grupo infestado apenas uma vez os animais foram sacrificados $24 \mathrm{~h}$ após a fixação dos carrapatos.

Após o sacrifício dos animais, foram coletadas amostras de tecidos de 0,5 $\mathrm{cm}^{2}$ (20-30 mg) do local de fixação dos carrapatos (pele) e de linfonodos drenantes (braquial ou cervical), sendo o material armazenado em tubo tipo "eppendorf" contendo $700 \mu \mathrm{L}$ de reagente Trizol (Invitrogen Corporation, 
Califórnia-USA). Procedeu-se com a trituração dos tecidos por 30 segundos utilizando homogeinizador Ultra-Turrax T8 (Ika-Werke GmbH \& Co., Alemanha), sendo as amostras armazenadas em freezer a $-70^{\circ} \mathrm{C}$ até o momento da extração do RNA.

\section{Inoculação de saliva de carrapatos em cobaias}

Foram utilizadas 20 cobaias, sendo que 10 receberam três inoculações intradérmicas sucessivas com saliva (40 $\mu \mathrm{L} /$ dorso) e 10 receberam PBS $0,1 \mathrm{M} \mathrm{pH}$ 7,2 (sete dias de intervalo entre inoculações). Três dias antes da primeira inoculação, foi realizada a tricotomia no local da inoculação para facilitar a visualização, assepsia e marcação do local escolhido. Até o momento da coleta da pele, o pêlo dos animais foi mantido curto utilizando uma tesoura. As inoculações foram realizadas de forma intradérmica com uso de seringas com agulha 12,7 x 0,33 mm (Becton-Dickinson, NJ). A coleta da pele e linfonodos foi realizada 3 e $6 \mathrm{~h}$ pós-inóculo. Foram colhidas amostras de tecidos de $0,5 \mathrm{~cm}^{2}(20-30 \mathrm{mg})$ do local do inóculo (pele) e dos linfonodos drenantes (braquial ou cervical), sendo o material processado como previamente descrito para as cobaias infestadas com carrapatos.

\section{Extração de RNA}

O RNA total dos tecidos foi extraído utilizando o reagente Trizol (Invitrogen) e o kit para extração de RNA (RNAeasy mini-kit, Quiagen, Califórnia- USA), seguindo o protocolo recomendado pelo fabricante, com algumas alterações. Brevemente, esperou-se o descongelamento à temperatura ambiente de cada amostra e 
procedeu-se à retrituração dos tecidos (descrito anteriormente). A seguir, adicionouse $200 \mu$ l de clorofórmio (Sigma) e, após 15 minutos, realizou-se uma centrifugação a $12000 \times$ g por 15 minutos a $4^{\circ} \mathrm{C}$. A fase aquosa foi transferida para outro tubo e acrescentou-se etanol $70 \%$ em proporções iguais à amostra (v:v). A solução amostra/etanol foi agitada delicadamente e transferida para uma coluna de afinidade para RNA. Em seguida, foram adicionados os tampões específicos (kit), intercalados por rápidas centrifugações por 15 segundos a 10.000 rpm cada. As amostras de RNA foram eluídas da coluna com $30 \mu \mathrm{l}$ de água milliQ livre de RNAase, sendo armazenadas a $-70^{\circ} \mathrm{C}$, até a confecção do DNA complementar (cDNA). Para determinar a concentração de RNA $(\mu \mathrm{g} / \mu \mathrm{l})$ nas amostras utilizou-se o aparelho GeneQuant (Pharmacia, USA). A integridade do RNA e a possibilidade de contaminação das amostras com DNA genômico foi determinada realizando-se uma eletroforese do material em gel de agarose contendo formaldeído (SAMBROOK et al., 1989).

\section{Reação de RT-PCR}

O cDNA foi sintetizado através de uma reação de transcrição reversa, com a utilização da enzima M-MVL Reverse Transcriptase, (Promega Corporation, Madison, WI) utilizando $1 \mu \mathrm{g}$ de RNA. As reações em cadeia com polimerase (PCRs) foram realizadas com a enzima Taq polimerase (Taq DNA Polymerase, Promega), dNTP e primers específicos para cada citocina. As PCRs foram feitas no termociclador PTYC-100 (MJ Research, Watertown, MA). As condições básicas da reação foram estabelecidas para cada citocina analisada. De forma geral as condições foram: 1 minuto a $95^{\circ} \mathrm{C}$ para desnaturação, seguido por 27 ciclos de 1 
minuto a $94^{\circ} \mathrm{C}, 1$ minuto a $58^{\circ} \mathrm{C}$ para o anelamento dos primers às fitas do cDNA e 2 minutos $72^{\circ} \mathrm{C}$ de extensão acrescidos de um passo de extensão final de 7 minutos a $72^{\circ} \mathrm{C}$. Além das reações para detecção de mensagem para citocinas, as amostras também foram submetidas a PCRs para gliceraldeido-3-fosfato desidrogenase (G3PDH) (KLUNNER et al., 2001), um gene de expressão constitutiva que foi utilizado como controle positivo das reações de amplificação. Como controles negativos das reações foram submetidas a PCR amostras contendo $1 \mu \mathrm{g}$ de RNA acrescidas de Taq polimerase, dNTP e primers para descartar a presença de contaminação com DNA genômico no RNA total ou a amplificação de produtos inespecíficos.

Os produtos de PCR obtidos para o gene constitutivo e citocinas foram separados por grupos de animais e submetidos à eletroforese em géis individuais. Em cada gel de poliacrilamida a 6\%, foram aplicados $5 \mu \mathrm{l}$ dos produtos de PCR. Os géis foram corados com nitrato de prata $0,2 \%$, secos (temperatura ambiente) e digitalizados, em tons de cinza, utilizando scanner com resolução de 300 dpi. Os primers estão demonstrados na tabela 1.

\section{Análise da intensidade de expressão de mRNA}

A obtenção dos valores numéricos referentes à intensidade das bandas para as citocinas presentes nos géis foi realizada utilizando o programa ImageTool (The University of Texas Health Science Center- San Antonio, USA). Seguindo as orientações do programa, as imagens dos géis já digitalizadas foram padronizadas em relação ao seu tamanho e tonalidade. Um dos géis contendo os produtos para o gene constitutivo foi utilizado como gel padrão para os ajustes de tamanho e 
tonalidade nos demais géis. Com base no mesmo gel padrão e controles negativos, foi determinada uma barra de calibragem, que serviu então de base de referência para o limiar de detecção das bandas no programa ImageTool, sendo então utilizados os valores de zero e 114 unidades arbitrárias como limite para detecção máxima e mínima das bandas das citocinas. Depois de localizadas as bandas, seguiram-se com as análises dos géis, nos quais o valor utilizado foi a razão entre a área e a intensidade (ou absorbância) em unidades arbitrárias de intensidade (UAI). Antes de serem submetidos à análise estatística, os valores numéricos obtidos em UAI para as citocina de interesse foram normalizados ao serem divididos pelos valores obtidos para os respectivos controles (G3PDH). Dessa forma, obteve-se dados referentes à maior ou menor expressão da intensidade de mRNA para as citocina em relação à intensidade do mRNA para o G3PDH.

\section{Análise estatística}

Para a comparação dos resultados relativos à intensidade de expressão das citocinas observadas na pele e linfonodos de animais infestados com carrapatos e inoculados com saliva foi utilizado o teste estatístico one-way ANOVA, seguido do teste de Tukey. Foram consideradas significativas comparações com um $\mathrm{P}$ menor que 0,05 . Ambos os testes estatísticos foram aplicados utilizando o programa GraphPad 3.0 (GraphPad Software Inc.). 


\section{RESULTADOS}

\section{Delineamento dos primers e padronização das RT-PCR para citocinas}

Embora cobaias (Cavia porcellus) sejam freqüentemente usadas em estudos de doenças como asma e tuberculose por desenvolverem sintomatologia e quadro clínico semelhante ao desenvolvido por humanos (DANHAY, et al., 1999; KLUNNER et al., 2001), os reagentes disponíveis para estudos com essa espécie ainda são escassos em comparação aos existentes para camundongos e humanos. Sendo assim, para se observar eventos imunológicos em cobaias, muitas vezes torna-se necessário desenvolver novas ferramentas ou adaptar metodologias desenvolvidas para outro modelo experimental.

Para se compreender o perfil de citocinas apresentado na pele e nos linfonodos de cobaias frente a antígenos da saliva de carrapatos, foi preciso delinear primers e estabelecer um protocolo para detectar RNA mensageiro (mRNA) para citocinas de cobaias, a saber: IL-4, IL-5, IL-10, TGF- $\beta$, IFN- $\gamma$, TNF- $\alpha$ e IL-12p40 (Tabela 1). As seqüências de mRNA de citocinas de cobaias utilizadas para delinear os primers foram obtidas no GeneBank (U34588, AF097510, AF191297, E25787, U77036, AB025724). Devido à inexistência de seqüência de mRNA para IL-4 de cobaias no GeneBank foram delineados primers baseados em regiões homólogas comuns às seqüências de mRNA de gato, cachorro, cavalo, porco e vaca, de acordo com trabalho de ROTTMAN e colaboradores (1996). 
Tabela 1. Seqüências dos primers utilizados para a detecção de mensagem para citocinas

\begin{tabular}{|c|c|c|}
\hline $\begin{array}{l}\text { Gene controle } \\
\text { Citocinas }\end{array}$ & $\begin{array}{l}\text { Sequência Primer Forward } \\
\text { Sequência Primer Reverse (a) }\end{array}$ & $\begin{array}{c}\text { Tamanho dos } \\
\text { produtos de PCR } \\
\text { (pb) }\end{array}$ \\
\hline G3PDH (b) & $\begin{array}{l}\text { CAAGGT CATCCCAGAGCTGAATG } \\
\text { AGAAACGAGCTTGACAAAGTGGTC }\end{array}$ & 246 \\
\hline IL-4(c) & $\begin{array}{l}\text { TATTAATGGGTCT CACCTACCA } \\
\text { TTGGCT TCAT TCACAGAACAG }\end{array}$ & 431 \\
\hline IL-5 & $\begin{array}{l}\text { CTGAGGATTTCTGITCCTGCAC } \\
\text { GGTCTCAGCCTTCAATTGTCC }\end{array}$ & 262 \\
\hline IFN-? & $\begin{array}{l}\text { CAGAGCCAAATCGTCTCCTTC } \\
\text { TATTTGGATGCTCTCCGGC }\end{array}$ & 296 \\
\hline TNF- $\alpha$ & $\begin{array}{l}\text { CAGCCGCTCACACTCAGATCAG } \\
\text { TGATGGCAGAGAGAAGGTTGAC }\end{array}$ & 301 \\
\hline IL-12p 40 & $\begin{array}{l}\text { GGATCCAAT GGCAAGACCTT } \\
\text { TGAATAGCATCCACCACCACC }\end{array}$ & 259 \\
\hline IL -10 & $\begin{array}{l}\text { GCTGGACAACGTGCTGT TAAAC } \\
\text { GACACCTIGGTCT TGGAGCTTA }\end{array}$ & 283 \\
\hline TGF- $\beta$ & $\begin{array}{c}\text { TGACCCGCGTGTTAATGGI } \\
\text { CCAGTGACAT CAAAGGACAACC }\end{array}$ & 283 \\
\hline
\end{tabular}

(a) Primers demonstrados na posiçäo $5 \rightarrow 3^{\prime}$.

(b) Primers descritos em Wunner et al., 2001.

(c) Primers descritos em Rottman et al., 1996.

Os demais primers foram desenhados a partir das sequeências obtidas no gene bank utilizando o programa Primer Express 2.0 (Applied Biosystems, USA) 
Visando encontrar as melhores condições de reação para os primers empregados, primeiro determinou-se qual a temperatura ideal de anelamento e a quantidade de ciclos de amplificação. Para a padronização da temperatura de anelamento, variou-se a temperatura de 54 a $60^{\circ} \mathrm{C}$ e determinou-se que a temperatura de $58^{\circ} \mathrm{C}$ foi a que apresentou maior especificidade no anelamento dos primers. Também se testaram diferentes números de ciclos de amplificação (variou de 25 a 30 ciclos), sendo que 27 ciclos de amplificação foram estabelecidos como ideal, tanto para melhorar o rendimento das reações, quanto por não originar dímeros. Com a padronização das reações determinada, as amostras coletadas foram submetidas às condições de reações descritas na seção de materiais e métodos.

\section{Efeito da infestação de carrapatos na expressão de mRNA de citocinas na} pele de cobaias

Com o intuito de verificar o perfil de citocinas induzido por carrapatos em animais que desenvolvem resistência aos mesmos, determinou-se, de um modo geral, o padrão de expressão de mensagem para citocinas presentes na pele de cobaias infestadas com carrapatos e controles por RT-PCR, sendo os resultados apresentados na figura 1. Para assegurar que a RT-PCR funcionou, primeiramente foi verificada a expressão de um gene constitutivo (G3PDH) nos cDNAs sintetizados. Os resultados mostraram que esse gene foi amplificado em todas as amostras coletadas nos animais infestados. 
No entanto, a semelhança na expressão de mRNA para algumas citocinas observadas na figura 1, dificulta a comparação entre o grupo de cobaias infestadas uma vez com o grupo de cobaias infestadas três vezes e controles. $\mathrm{O}$ fato de se verificar uma certa desigualdade na intensidade das bandas obtidas para o gene constitutivo, mesmo partindo da mesma quantidade de RNA para a síntese do cDNA (1 $\mu \mathrm{g})$, pode gerar dúvida quando da comparação entre os grupos analisados. Dessa forma, tornou-se necessário realizar a quantificação da intensidade de expressão de mRNA das citocinas detectadas nas cobaias infestadas e controles. Para se determinar com maior precisão a real expressão de mensagem das citocinas detectadas em gel, seguiu-se com a normalização da intensidade de expressão das citocinas em relação à intensidade de expressão do gene constitutivo correspondente (descrito em materiais e métodos). Os valores obtidos em UAI para essas citocinas foram representados em gráficos (Fig. 2) e submetidos à análise estatística (Tab. 2).

Dentre as três citocinas detectadas na pele dos animais, TNF- $\alpha$ foi a única a demonstrar um pequeno aumento, sendo este significativo, na intensidade de expressão de mRNA (aumento de 3,3 vezes) comparando-se o grupo uma vez com o três vezes infestado $(P<0,05)(T a b .2)$. Embora não significativa do ponto de vista estatístico, também se observou uma ligeira redução na intensidade de mensagem (redução de 2,3 vezes) para TNF- $\alpha$ comparando-se a média da primeira infestação com o controle (Tab. 2).

Embora tenha sido detectada a expressão de mRNA para IFN- $\gamma$ na pele de alguns animais pertencentes aos grupos infestados uma vez e três vezes (Fig. 2), a análise estatística da média dos grupos infestados demonstrou não haver 

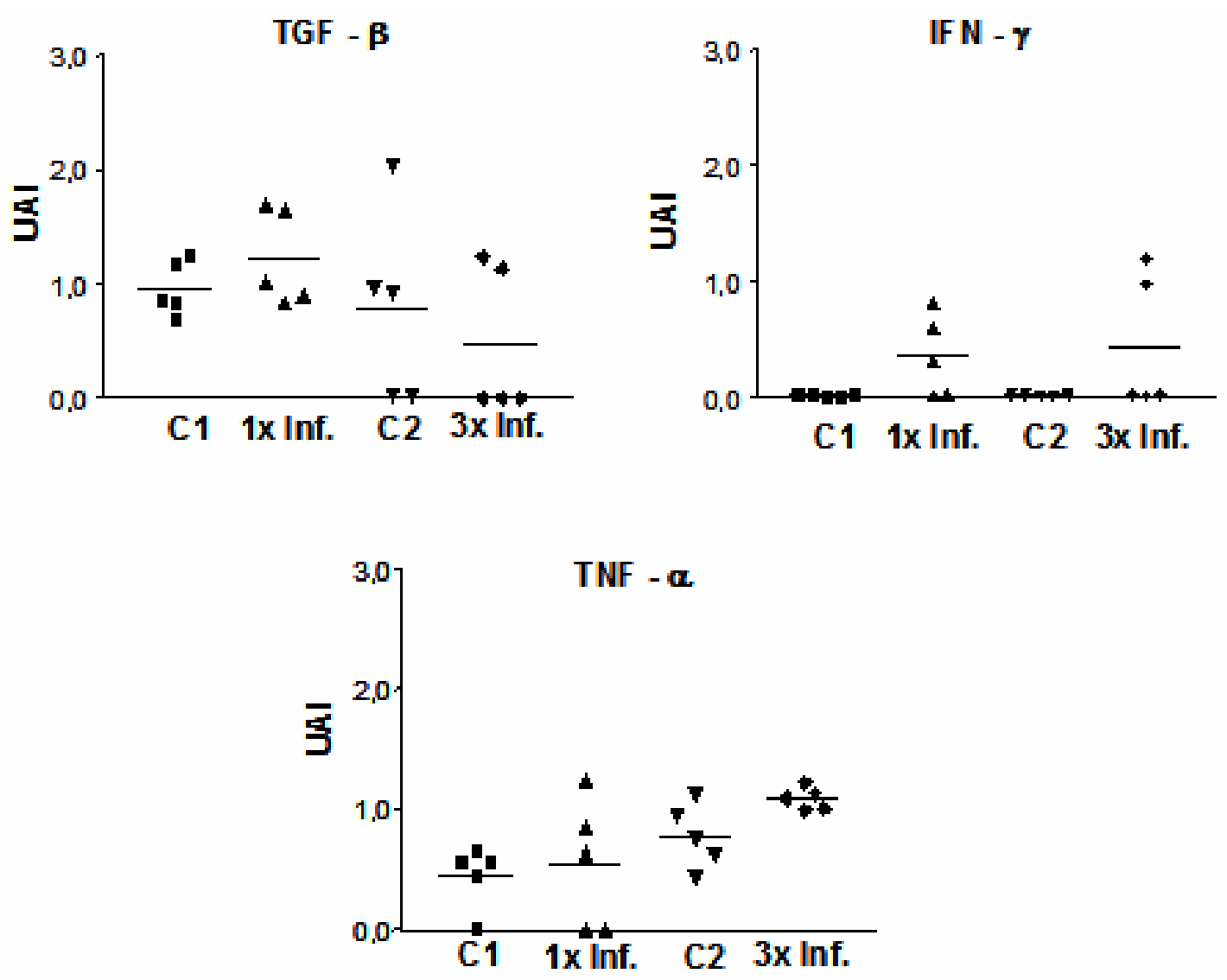

Figura 2. Intensidade de expressão de mRNA para citocinas na pele de cobaias infestadas com carrapatos. Grupos controles (C1 e C2), 1 e 3 vezes infestados tiveram amostras de pele retiradas, sendo a expressão das citocinas detectada por RT-PCR. A intensidade de expressão de mRNA foi obtida com o programa ImageT ool 2.0, normalizada conforme descrição nos Materiais e Métodos, sendo os valores traduzidos como Unidades Arbitrárias de Intensidade (UAI).

Os resultados foram submetidos à análise estatística apresentada na Tabela 2. 
Tabela 2 - Análise de citocinas na pele de cobaias infestadas com carrapatos $(n=5)$

\begin{tabular}{|c|c|c|c|c|}
\hline \multirow[b]{2}{*}{ Grupos } & \multicolumn{4}{|c|}{ Unidade Arbitrária de Intensidade $(M \pm D P)^{3}$} \\
\hline & Controle $1^{1}$ & $1 \mathrm{x}$ Inf. $^{2}$ & Controle $2^{1}$ & $3 x \operatorname{lnf}^{2}$ \\
\hline \multicolumn{5}{|c|}{ Citocinas } \\
\hline$T G F-\beta$ & $0,95 \pm 0,24 a^{4}$ & $1,21 \pm 0,42 a A^{4}$ & $0,79 \pm 0,84 a$ & $0,47 \pm 0,67 a A$ \\
\hline $\mathrm{IFN}-\gamma$ & $0,02 \pm 0,01 a$ & $0,44 \pm 0,59 a A$ & $0,02 \pm 0,01 a$ & $0,50 \pm 0,54 a A$ \\
\hline TNF- $\alpha$ & $0,45 \pm 0,26 a$ & $0,55 \pm 0,55 a A$ & $1,00 \pm 0,42 a$ & $1,39 \pm 0,31 a B$ \\
\hline
\end{tabular}

${ }^{1}$ Animais dos grupos controle tiveram câmaras de alimentação coladas ao dors o, sendo a coleta dos linfonodos realizada so mesmo tempo dos animais infestados.

${ }^{2} 1 \mathrm{x}$ ou $3 \mathrm{x}$ Inf.: Grupos com cobsias uma ou três vezes infes tados com carrapatos.

${ }^{3} \mathrm{O}$ s resultados foram apresentados como média (M) \pm desvio padräo (DP) da análise da express äo de mensagem de citocinas mensuradas em Unidades Arbitrárias de Intensidade.

4 Letras minúsculas correspondem a comperaçäo entre grupos infestados com seus respectivos controles, enquanto que letras maiúsculas säo usadas para a comparaçăo entre os grupos infestados ( $1 \mathrm{x} \operatorname{Inf} . \mathrm{X} 3 \mathrm{x}$ Inf.). As médias foram comparadas pelo teste de one-way ANOVA, seguido pelo teste estatístico de Tukey. Médias seguidas de letras distintas demonstram diferença estatística entre si $(\mathrm{P}<0,05)$.

Somente as citocinas que tiveram express äo de mensagem estäo apresentadas. 
diferença significativa entre eles e quando foram comparados com os controles (Tab. 2).

Notou-se ainda uma expressão aumentada de TGF- $\beta$ para todos os grupos, inclusive nos controles, sugerindo que essa citocina seja constitutivamente expressa na pele desses animais. De fato, TGF- $\beta$ foi encontrado também em amostras de pele normal de cobaias (resultados não mostrados).

A intensidade de expressão para as citocinas IL-4, IL-5, IL-10 e IL-12p40 não foi detectada na pele de nenhum dos grupos analisados, embora seja possível observar amplificação de produtos de PCR para essas citocinas nos linfonodos obtidos dos grupos infestados e na pele e linfonodos de cobaias inoculadas com saliva de carrapatos (Figs. 1, 3 e 7).

\section{Efeito da infestação de carrapatos na expressão de mRNA de citocinas nos linfonodos de cobaias}

A expressão de mRNA para citocinas detectadas nos linfonodos de cobaias infestadas uma e três vezes com carrapatos e controles está apresentada na figura 3. Nota-se um perfil de expressão muito semelhante para as citocinas detectadas nos grupos analisados. Devido a isso, os resultados apresentados na figura 4 demonstram de maneira mais clara as diferenças de intensidade de mensagem das citocinas detectadas entre os grupos infestados e controles.

Diferente do observado na pele foi detectada mensagem para IL-12p40 nos linfonodos de alguns animais dos grupos infestados com carrapatos e controles. A média apresentada pelo grupo três vezes infestado demonstra haver um aumento na intensidade de expressão de IL-12p40 em relação ao grupo infestado uma vez 


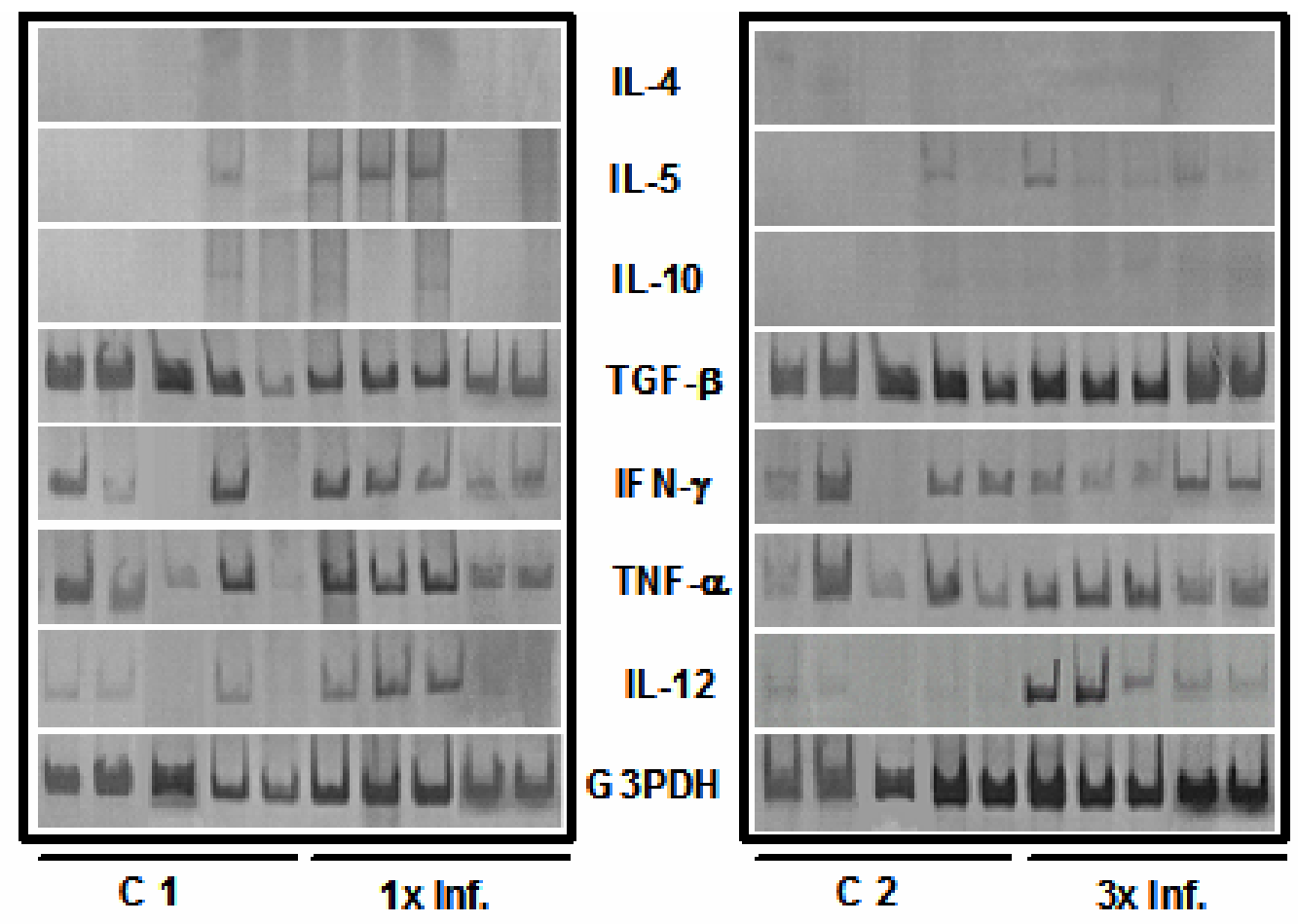

Figura 3. Expressão de mRNA para citocinas em linfonodos de cobaias infestadas com carrapatos. Coletaram-se linfonodos de cobaias 1 e 3 vezes infestadas com carrapatos após 24 horas de fixação. Cobaias não infestadas foram utilizadas como controle ( $\mathrm{C} 1$ e C2). A expressão de mensagem foi detectada por RT-PCR e visualizada em gel de poliacrilamida corado $\infty$ m nitrato de prata. Foram utilizados 5 animais por grupo. 


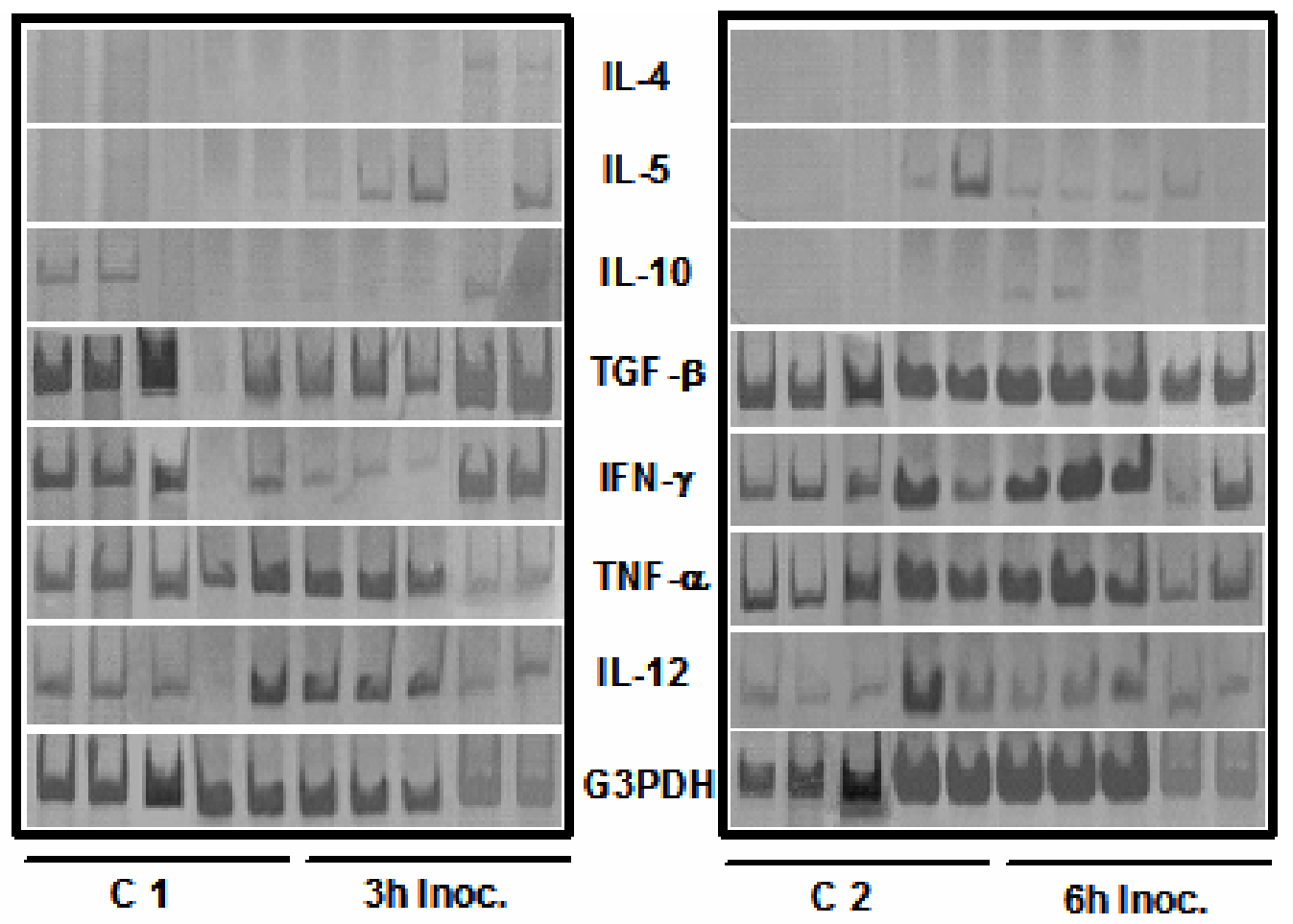

Figura 7. Expressão de mRNA para citocinas em linfonodos de cobaias inoculadas com saliva. Coletaram-se linfonodos de cobaias 3 e $6 \mathrm{~h}$ após o terceiro inóculo com saliva (40 $\mu \mathrm{V}$ inóculo/ animal). Cobaias inoculadas com PBS foram utilizadas como controle ( $\mathrm{C} 1$ e $\mathrm{C} 2$ ). A expressão de mensagem foi detectada por RT-PCR e visualizada em gel de poliacrilamida corado $\infty$ m nitrato de prata. Foram utilizados 5 animais por grupo. 


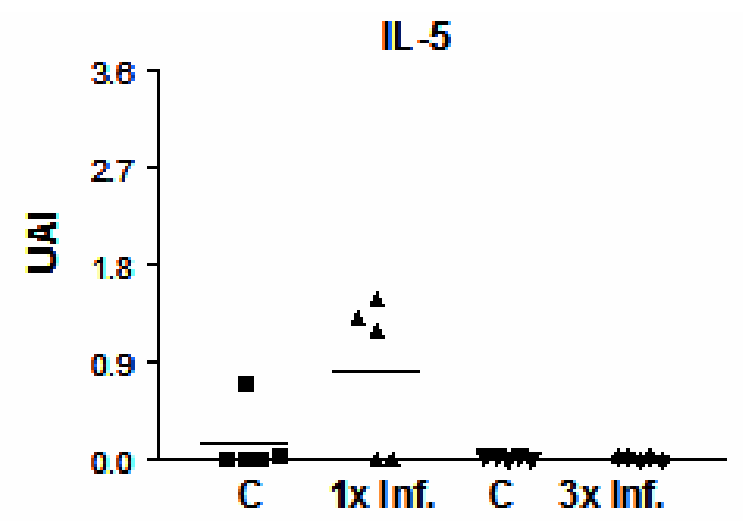

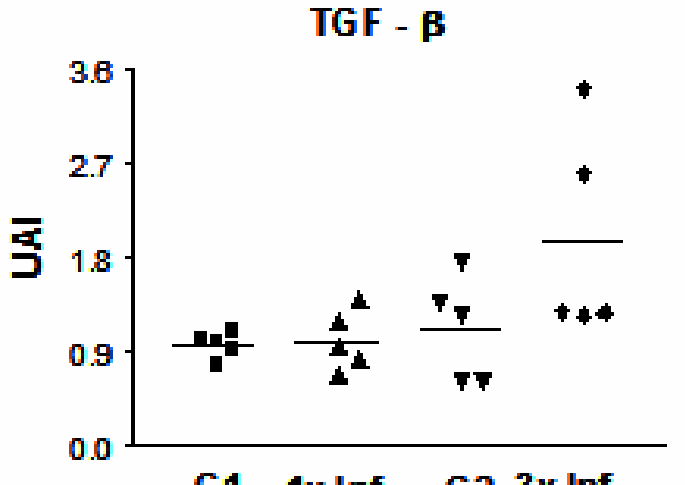

C1 1x Inf. C2 3x Inf.

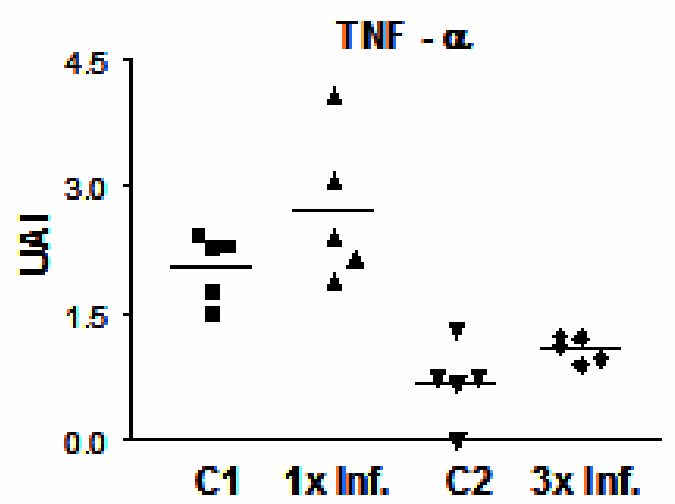

IF $-\boldsymbol{\gamma}$
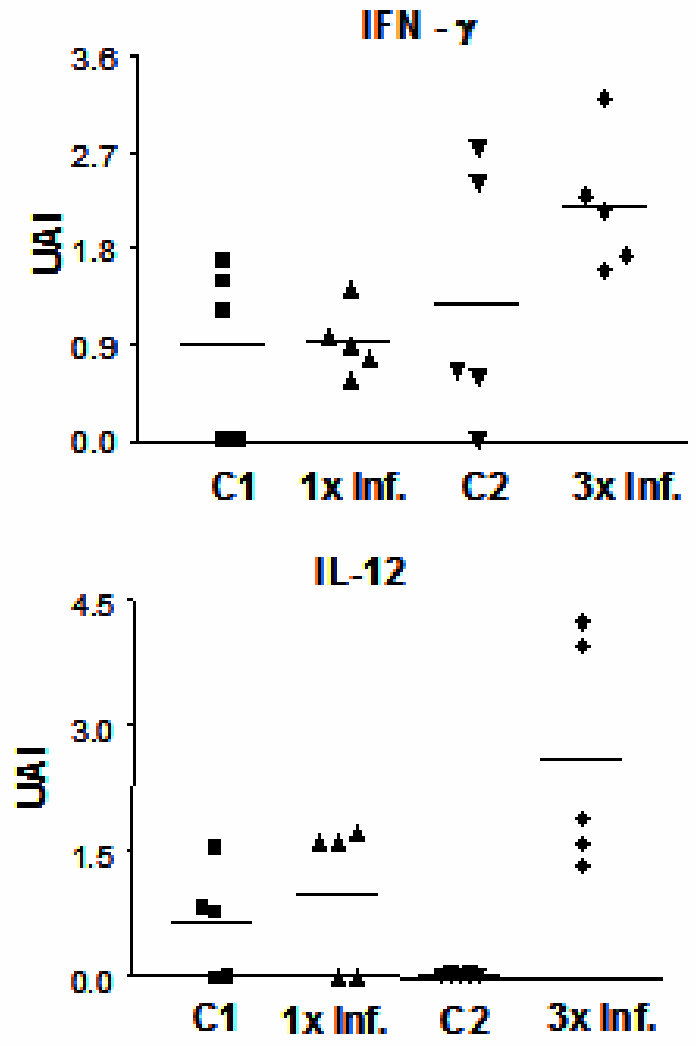

Figura 4. Intensidade de expressão de mRNA para citocinas nos linfonodos de cobai as infestadas com carrapatos. Coletaram-se linfonodos de animais controles (C1 e C2), 1 e 3 vezes infestados, sendo a expressão das citocinas detectada por RT-PCR. A intensidade de expressão de mRNA foi obtida com o programa ImageTool 2.0, normalizada conforme descrição nos Materiais e Métodos, sendo os valores traduzidos como Unidades Arbitrárias de Intensidade (UAI).

Os resultados foram submetidos à análise estatística apresentada na Tabela3. 
e controles (Fig.4). A análise estatística demonstrou ser um aumento de 2,6 vezes maior na intensidade de IL-12p40 nos linfonodos do grupo infestado três vezes em comparação com o grupo uma vez infestado. Quando comparado com o grupo controle 1, o grupo três vezes infestado apresentou um aumento 4,0 vezes maior de intensidade para IL-12p40; porém a comparação com o grupo controle 2 demonstrou um aumento muito maior (13,0 vezes) (Tab.3).

Outra citocina que apresentou aumento na intensidade de expressão foi TNF$\alpha$. De maneira inversa a IL-12p40, TNF- $\alpha$ demonstrou maior intensidade de mensagem nos linfonodos do grupo uma vez infestado em relação aos linfonodos do grupo três vezes infestados (Fig. 4). Esse aumento observado para TNF- $\alpha$ no grupo uma vez infestado demonstrou ser 2,5 vezes maior em comparação ao grupo três vezes infestado (Tab. 3).

TGF- $\beta$ mostrou-se presente em todas as amostras testadas, independentemente do grupo experimental (Figs. 3 e 4). Podendo ser notado um aumento de expressão em duas cobaias do grupo três vezes infestado com carrapatos em comparação ao controle (Fig. 4 e Tab. 3). Essa variação dentro de um mesmo grupo poderia ser explicada pela diferença nos tempos de fixação dos carrapatos existente nas primeiras horas após a liberação dos ácaros nas câmaras de alimentação, podendo variar de 3 a 14 h, apesar de se ter colhido material 24 h após a fixação, os carrapatos se fixam em tempos desiguais.

A intensidade de mensagem para IFN- $\gamma$ apresentou uma tendência de aumento de 2,4 vezes mais no grupo infestado três vezes em comparação ao grupo uma vez infestado (Fig. 4), embora não tenha sido relevante 
Tabela 3 - Análise de citocinas nos linfonodos de cobaias infestadas com carrapatos $(n=5)$

\section{Grupos $\quad{\text { Controle } 1^{1} \quad \text { 1x Inf. }^{2} \quad \text { Controle }^{1}}^{1} \quad 3 x$ Inf. $^{2}$}

\section{Citocinas}

$\begin{array}{lllll}\text { IL-5 } & 0,16 \pm 0,31 a^{4} & 0,81 \pm 0,73 b B^{4} & 0,02 \pm 0,01 a & 0,02 \pm 0,01 a A \\ \text { TGF- } \beta & 0,96 \pm 0,13 a & 1,00 \pm 0,28 a A & 1,11 \pm 0,50 a & 1,96 \pm 1,00 a A \\ \text { IFN- }- & 0,89 \pm 0,82 a & 0,92 \pm 0,32 a A & 1,27 \pm 1,21 a & 2,19 \pm 0,63 a A \\ \text { TNF- } \alpha & 2,04 \pm 0,39 a & 2,71 \pm 0,88 a A & 0,69 \pm 0,46 a & 1,08 \pm 0,15 a B \\ \text { IL-12 } & 0,65 \pm 0,65 a & 0,99 \pm 0,90 a A & 0,02 \pm 0,01 a & 2,60 \pm 1,38 b B\end{array}$

${ }^{1}$ Animais dos grupos controle tiveram câmaras de alimentaçäo coladas ao dorso, sendo a coleta dos linfonodos realizada so mesmo tempo dos animais infestados.

2 1x ou $3 x$ Inf.: Grupos com cobaias uma ou três vezes infestados com carrapatos.

${ }^{3}$ Os resultados foram apresentados como média $(M) \pm$ desvio padräo (DP) da análise da expressäo de mensagem de citocinas mensuradas em Unidades Arbitrárias de Intensidade.

${ }^{4}$ Letras minúsculas correspondem a comparaçăo entre grupos infestados com seus respectivos controles, enquanto que letras maiúsculas săo usadas para a comparaçäo entre os grupos infes tados (1x Inf. X 3x Inf.). As médias foram comparadas pelo teste de one-way ANOVA, seguido pelo teste estatístico de Tukey. Médias seguidas de letras distintas demonstram diferença estatística entre si $(P<0,05)$.

Somente as citocinas que tiveram expressäo de mens agem estäo apresentadas. 
estatisticamente quando os grupos infestados foram comparados entre si e com os controles (Tab. 3).

Somente nos linfonodos de cobaias infestadas uma vez foi detectada expressão de mRNA para IL-5 (Figs. 3 e 4), sendo apontado pela análise estatística um aumento significativo na expressão dessa citocina em relação ao controle (5,0 vezes maior) (Tab. 3).

Outras citocinas, como IL-4 e IL-10 não foram detectadas nos linfonodos de cobaias infestadas ou não com carrapatos (Figs. 3 e 4).

\section{Efeito da inoculação de saliva de carrapatos na expressão de mRNA de citocinas na pele de cobaias}

A inoculação de saliva com seringa e agulha foi realizada com o objetivo de observar a interferência dos processos de tricotomia, colocação das câmaras de alimentação e tempo de fixação dos carrapatos na produção de citocinas nas amostras obtidas dos hospedeiros frente a infestações com carrapatos.

Assim sendo, foram realizadas três inoculações de saliva em cobaias, respeitando um intervalo de sete dias entre as inoculações. Devido à ausência de carrapatos não há uma constante salivação no local e dessa forma, o estímulo para a produção de citocinas também não é contínuo. Então, após a última inoculação, a pele foi coletada nos tempos de três e seis horas.

De forma similar ao observado no material coletado em cobaias infestadas

com carrapatos, foi detectado mRNA para o gene constitutivo G3PDH na amostras obtidas de cobaias inoculadas com saliva (Fig. 5 e 7 ). 


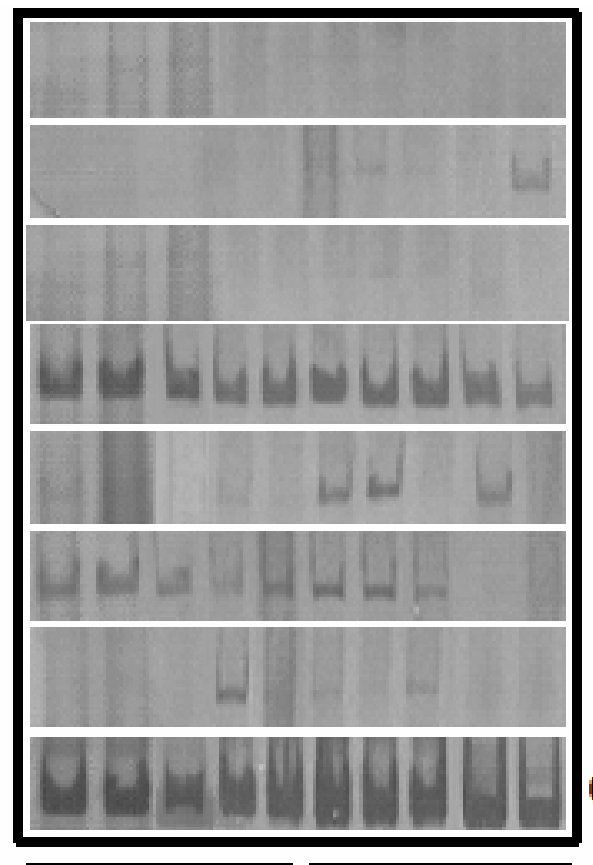

C 1

3h Inoc.

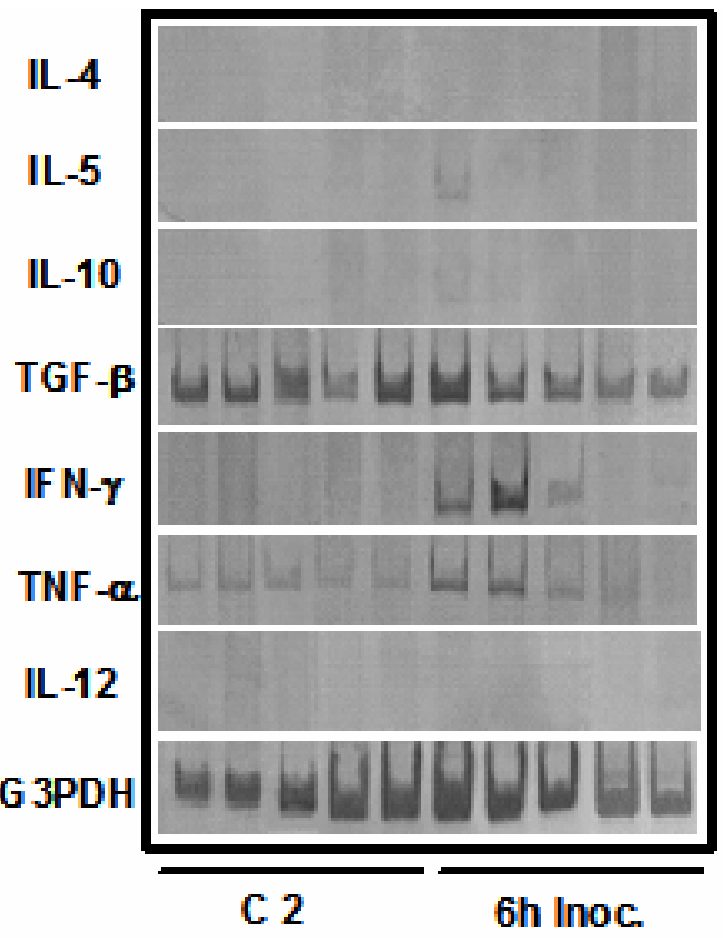

Figura 5. Expressão de mRNA para citocinas na pele de cobaias inoculadas com saliva. Coletaram-se amostras de pele de cobaias 3 e $6 \mathrm{~h}$ após o terceiro inóculo com saliva (40 $\mu \mathrm{V}$ inóculo/ animal). Cobaias inoculadas com PBS foram utilizadas como controle ( $\mathrm{C} 1$ e $\mathrm{C} 2$ ). A expressão de mensagem foi detectada por RT-PCR e visualizada em gel de poliacrilamida corado $\infty \mathrm{m}$ nitrato de prata. Foram utilizados 5 animais por grupo. 
A expressão de mRNA para TGF- $\beta$ mostrou-se presente na maioria das amostras testadas, tanto nos animais inoculados quanto nos controles. A análise estatística demonstrou não haver diferença significativa na intensidade de expressão para TGF- $\beta$ nos grupos inoculados e controles, reafirmando a sugestão que esta citocina possa ser de expressão constitutiva em cobaias (Figs 5 e 6, Tab. $4)$.

Apesar de haver expressão de mensagem para as citocinas IFN- $\gamma$ e TNF- $\alpha$ (Fig 5), nenhuma das citocinas analisadas mostrou diferença estatística na intensidade de expressão após a normalização contra o gene G3PDH (Fig. 6 e Tab. 4).

As citocinas IL-4, IL-5 e IL-10 não apresentaram expressão de mRNA na pele, tanto nos grupos experimentais como nos controles (Fig. 5). Para IL-12p40 observou-se expressão de mensagem em uma cobaia controle três horas depois de inoculada com PBS e em três inoculadas com saliva (Fig. 5).

\section{Efeito da inoculação de saliva de carrapatos na expressão de mRNA de citocinas nos linfonodos de cobaias}

O perfil de citocinas detectados nos linfonodos coletados três e seis horas após inoculação de saliva em cobaias mostrou-se semelhante ao apresentado nos linfonodos coletados dos animais infestados com carrapatos.(Fig 3 e 7).

As diferenças observadas na intensidade de expressão de TNF- $\alpha$ e IL-12p40 nos linfonodos de cobaias infestadas com carrapatos não se repetiram nos linfonodos coletados de cobaias inoculadas com saliva após a normalização contra o gene constitutivo (Fig. 8, Tab. 3 e 5). 
Tabela 4 - Análise de citocinas na pele de cobaias inoculadas com saliva $(40 \mu /$ animal $),(n=5)$

\begin{tabular}{|c|c|c|c|c|}
\hline \multirow[b]{2}{*}{ Grupos } & \multicolumn{4}{|c|}{ Unidade Arbitrária de Intensidade $(M \pm D P)^{3}$} \\
\hline & Controle $1^{1}$ & 3h Inoc. ${ }^{2}$ & Controle $2^{1}$ & $6 \mathrm{~h}$ Inoc. $^{2}$ \\
\hline \multicolumn{5}{|l|}{ Citocinas } \\
\hline TGF $-\beta$ & $1,15 \pm 0,60 a^{4}$ & $0,76 \pm 0,17 a A^{4}$ & $1,01 \pm 0,47 a$ & $0,66 \pm 0,10 a A$ \\
\hline $\mathrm{IFN}-\gamma$ & $0,02 \pm 0,01 a$ & $0,46 \pm 0,41 a A$ & $0,02 \pm 0,01 a$ & $0,33 \pm 0,30 a A$ \\
\hline TNF- $\alpha$ & $1,00 \pm 0,44 a$ & $0,31 \pm 0,30 \mathrm{aA}$ & $0,57 \pm 0,33 a$ & $0,57 \pm 0,34 a A$ \\
\hline
\end{tabular}

${ }^{1}$ Animais dos grupos controle foram inoculados PBS, sendo a coleta da pele realizada ao mesmo tempo dos animais inoculados comsaliva.

2

3 e $6 \mathrm{~h}$ Inoc: Grupos com cobaias que tiveram pele coletadas nos tempos 3 e 6 horas após incoulação de saliva.

${ }^{3}$ Os resultados foram apresentados como média (M) \pm desvio padräo (DF) da análise da expressão de mensagem de citocinas mensuradas em Unidades Arbit ár ias de Intensidade.

4 Letras minúsculas correspondem a comparaçäo entre grupos incculados com seus respectivos controles, enquanto que letras maiús culas säo us adas para a compar açäo entre os grupos incculados (3h Inoc. X 6h Inoc.). As médias foram comparadas pelo teste de one-way ANOVA, seguido pelo teste estatístico de Tukey. Médias seguidas de letras distintas demonstram diferença estatistica entre si $(\mathrm{P}<0,05)$.

Somente as citocinas que tiveram expressäo de mensagem estäo apresentadas. 
Tabela 5 - Análise de citocinas nos linfonodos de cobaias inoculadas com saliva (40 $\mathrm{u} /$ animal), ( $\mathrm{n}=5$ )

\begin{tabular}{|c|c|c|c|c|}
\hline \multirow[b]{2}{*}{ Grupos } & \multicolumn{4}{|c|}{ Unidade Arbitrária de Intensidade $(M \pm D P)^{3}$} \\
\hline & Controle 1 & 3h Inoc. ${ }^{2}$ & Controle $2^{1}$ & $6 \mathrm{~h} \operatorname{lnoc}^{2}$ \\
\hline \multicolumn{5}{|l|}{ Citocinas } \\
\hline IL-5 & $0,02 \pm 0,01 a$ & $0,50 \pm 0,49 a A$ & $0,58 \pm 0,96 a$ & $0,35 \pm 0,24 a A$ \\
\hline TGF- $\beta$ & $0,76 \pm 0,50 a$ & $1,37 \pm 0,27 a A$ & $1,25 \pm 0,44 a$ & $0,75 \pm 0,48 a A$ \\
\hline $\mathrm{IFN}-\gamma$ & $0,73 \pm 0,45 a$ & $0,65 \pm 0,57 a A$ & $1,05 \pm 0,53 a$ & $0,52 \pm 0,29 a A$ \\
\hline TNF- $\alpha$ & $1,02 \pm 0,33 a$ & $0,98 \pm 0,25 a A$ & $0,96 \pm 0,27 a$ & $0,79 \pm 0,24 a A$ \\
\hline IL-12 & $0,69 \pm 0,42 a$ & $0,75 \pm 0,35 a A$ & $1,04 \pm 0,42 a$ & $0,61 \pm 0,25 a A$ \\
\hline
\end{tabular}

${ }^{1}$ Animais dos grupos controle foram inoculados PBS, sendo a coleta de linfonodos realizada ao mes mo tempo dos animais inoculados com saliva.

$2_{3}$ e $6 \mathrm{~h}$ inoc: Grupos com cobsias que tiveram os linfonodos coletados nos tempos 3 e 6 horas spós inoculaçăo de saliva.

${ }^{3} \mathrm{O}$ s res ultados foram apresentados como média $(M) \pm$ desvio padrăo (DP) da análise da express ão de menssgem de citocinas mensuradas em Unidades Arbitrárias de Intensidade.

4 Letras minúsculas correspondem a comparaçäo entre grupos inoculados com seus respectivos controles, enquanto que letras maiús culas säo us adas para a comparação entre os grupos incculados (3h Inoc. X th Inoc.). As médias foram comparadas pelo teste de one-way ANOVA, seguido pelo teste estatístico de Tukey. Médias seguidas de letras distintas demonstram diferença estatistica entre si $(P<0,05)$.

Somente as citocinas que tiveram express äo de mensagem estão apresentadas. 

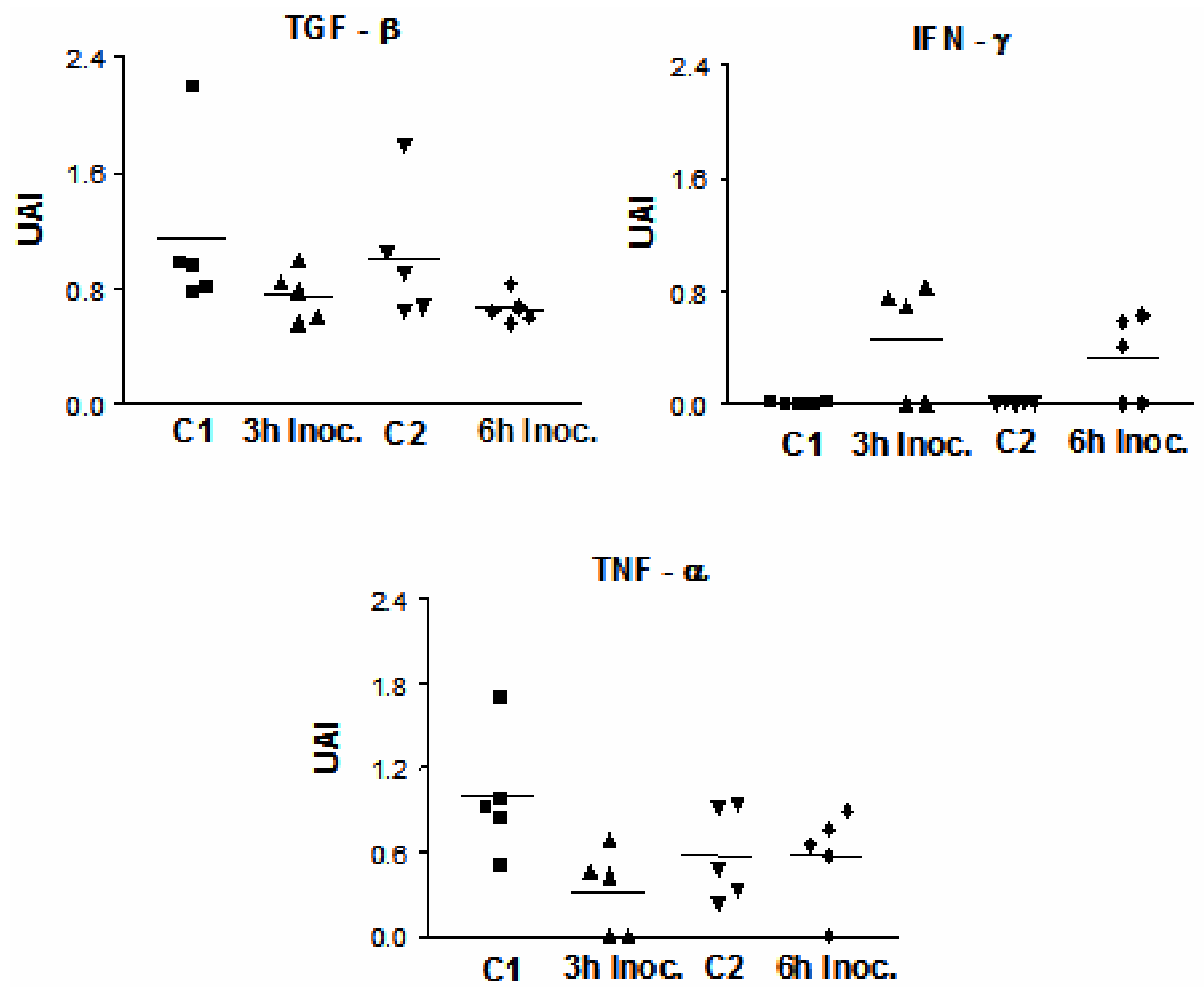

Figura 6. Intensidade de expressão de mRNA para citocinas na pele de cobaias inoculadas com saliva. Coletaram-se amostras da pele de cobaias 3 e 6h após o terceiro inóculo com saliva ( $40 \mu \mathrm{l} /$ inóculo/ animal). Cobaias inoculadas com PBS foram utilizadas como controle ( $\mathrm{C} 1$ e $\mathrm{C} 2$ ). A intensidade de expressão de mensagem foi detectada por RT-PCR seguida de análise com o programa ImageTool 2.0, conforme descrição nos Materiais e Métodos. Os valores obtidos foram representados como Unidades Arbitrárias de Intensidade (UAI).

Os resultados foram submetidos à análise estatística apresentada na Tabela 4. 
Foi detectada mensagem para TGF- $\beta$ na maioria das amostras testadas, tanto nos animais inoculados quanto nos controles (Fig 7). Como ocorrido nas demais amostras, nas quais se observou a expressão de mRNA para TGF- $\beta$, não houve diferença significativa na intensidade de mensagem para essa citocina entre os grupos inoculados e controles (Fig. 8 e Tab. 5)

Embora não tendo diferença significativa como demonstrada nos linfonodos de animais uma vez infestados com carrapatos, a expressão de mensagem para IL-5 foi observada nos linfonodos coletados três horas (Figs. 3 e 7). Também foi observada mensagem pala IL-5 nos linfonodos coletados seis horas após a inoculação com saliva (Fig. 7 e 8). Ao comparar a intensidade de expressão de IL5 entre os grupos inoculados e controles, a análise estatística não revelou nenhuma diferença significativa entre eles (Tab 5)

Uma tênue expressão de mRNA para IL-4 foi observada apenas em duas amostras de linfonodos coletados três horas após inoculação de saliva (Fig. 7). Assim como para IL-4, IL-10, também apresentou expressão de mRNA apenas em duas cobaias controles e duas cobaias inoculadas com saliva que tiveram os linfonodos coletados após 3 horas de inoculação (Fig. 7). 

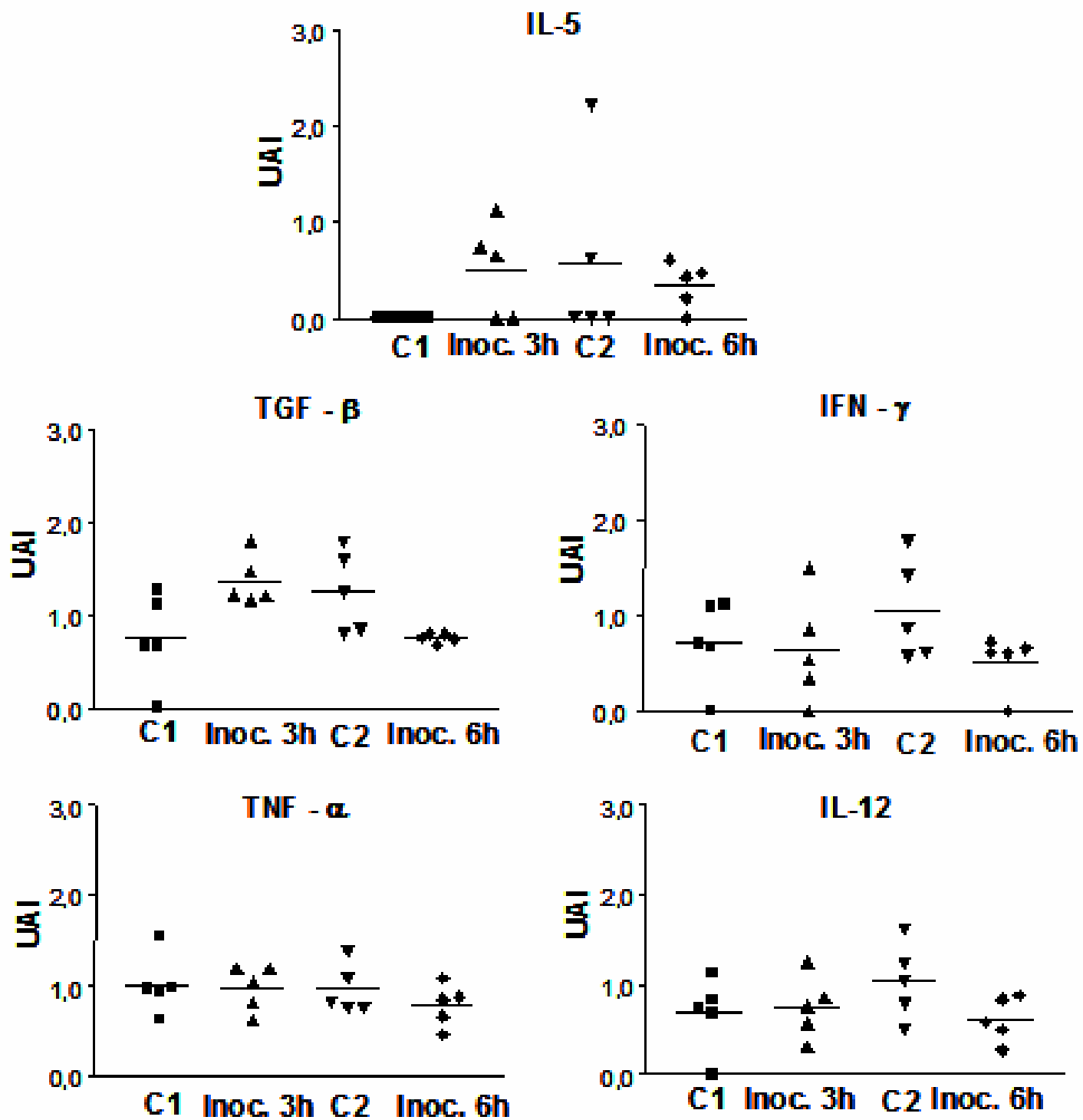

Figura 8. Intensidade de expressão de mRNA para citocinas nos linfonodos de cobaias inoculadas com saliva. Coletaram-se linfonodos de cobaias 3 e 6 h após o terceiro inóculo com saliva ( $40 \mu V$ inóculo/ animal). Cobaias inoculadas com PBS foram utilizadas como controle ( $\mathrm{C} 1$ e C2). A intensidade de expressão de mensagem foi detectada por RT-PCR seguida de análise com o programa ImageTool 2.0, conforme descrição nos Materiais e Métodos. Os valores obtidos foram representados como Unidades Arbitrárias de Intensidade (UAI).

Os resultados foram submetidos à análise estatística e são apresentados na Tabela 5 . 


\section{DISCUSSÃO}

O longo período de co-evolução entre os carrapatos e seus hospedeiros vertebrados, cerca de 37 milhões de anos (HOOGSTRAAL \& KIM, 1985), veio a favorecer a seleção de ectoparasitas que dispusessem de "ferramentas" para conter a resposta hemostática, inflamatória e imunológica de seus hospedeiros. Isso tem sido demonstrado em diversos trabalhos (WIKEL, 1996 b).

Outro fator que deve ter desempenhado importante pressão na seleção desses artrópodes é a necessidade de prolongado período de fixação para obtenção de uma alimentação adequada. Esse requerimento poderia vir a desencadear mecanismos de defesa do hospedeiro os quais contribuiriam com a rejeição dos mesmos. Mas não, os carrapatos, assim como outros parasitas, conseguem modular a imunidade de seus hospedeiros (WIKEL,1996 b). Cada vez mais se tem descoberto componentes presentes na saliva de carrapatos que podem ser responsáveis pela modulação dessa resposta imune (RIBEIRO et al, 1985; RIBEIRO, 1989). No entanto, mesmo diante de componentes salivares imunomoduladores, alguns hospedeiros ainda são capazes de demonstrar resistência a carrapatos. Sendo esta mensurada pela redução dos ectoparasitas que se alimentam adequadamente numa infestação desafio, diminuição no peso de ingurgitamento, aumento do período de ingurgitamento, reduzida capacidade de larvas e ninfas alimentadas sofrerem ecdise, fecundidade diminuída e ainda morte dos carrapatos que se fixam (CHABAUD, 1950; ALLEN, 1989; BECHARA et al., 1995). 
Este estudo pretendeu contribuir com uma linha de pesquisa cujo objetivo é compreender melhor a interação carrapatos $R$. sanguineus-hospedeiros. Como já descrito, essa relação é particularmente interessante já que o hospedeiro natural (cão) assim como camundongos, não desenvolvem resistência alguma, mesmo após diversas infestações. Por outro lado, cobaias desenvolvem forte resposta imunológica durante re-infestações, a qual resulta em resistência.

No atual trabalho, procurou-se contribuir para o entendimento dos mecanismos imunológicos envolvidos na interação carrapato-hospedeiro resistente (cobaias). Assim sendo, realizou-se a análise da expressão de mRNA das citocinas IL-12p40, IFN- $\gamma$ e TNF- $\alpha$, polarizadoras de padrão Th1; assim como a expressão das citocinas IL-4, IL-10, IL-5 e TGF- $\beta$, polarizadoras de padrão Th2, na pele e linfonodos regionais de cobaias infestadas uma ou diversas vezes com carrapatos.

Independentemente do tecido analisado ou tratamento ministrado, a citocina que teve maior expressão, tanto em intensidade quanto em freqüência de detecção nas amostras analisadas, foi o TGF- $\beta$. Uma das hipóteses levantadas para explicar esse resultado foi que estaríamos observando um "efeito câmara" já que ambos os grupos, controle e experimental, tinham câmaras fixas ao seu dorso. No entanto, amostras de pele e linfonodos de animais normais também expressavam TGF- $\beta$ (resultados não mostrados), sugerindo que essa citocina apresente uma expressão constitutiva em cobaias. Baixa expressão espontânea de mensagem para TGF- $\beta$, assim como de outras citocinas, também foi observada na pele e linfonodos de cobaias da linhagem Albany (SCAROZZA et al., 1998). 
TNF- $\alpha$ é uma citocina pró-inflamatória produzida por diversas células como macrófagos, células T CD4 e polimorfonucleares. Essa citocina possui uma vasta gama de efeitos sobre diferentes tipos de células, um deles está relacionado com a indução da produção de quimiocinas em células inflamatórias, incluindo macrófagos, contribuindo assim para o desenvolvimento de respostas mediadas por células (KOBAYASHI et al., 2001). Devido a sua importância na mediação da resposta imune celular, a detecção de mensagem para TNF- $\alpha$ na pele e linfonodos de cobaias infestadas com carrapatos poderia indicar a presença de imunidade celular no desenvolvimento de resistência a carrapatos. Embora os nossos resultados tenham apontado para uma alteração estatisticamente significativa na intensidade de expressão para TNF- $\alpha$ de cobaias infestadas três vezes em relação a uma vez infestadas (redução para linfonodos e aumento para pele, Tabs. 2 e 3) não consideramos tal fenômeno relevante, pois também houve diferença entre os grupos controle (C1 e C2). A origem da variação observada entre os grupos controles é desconhecida, sobretudo porque ela não ocorreu para as demais citocinas.

Alguns estudos têm demonstrado que carrapatos modulam negativamente a produção de IFN- $\gamma$ em hospedeiros suscetíveis (KOPECKY et al., 1999; FERREIRA \& SILVA, 1998). Os dados obtidos neste trabalho sugerem que embora a análise estatística não tenha apontado uma diferença significativa, houve aumento de intensidade de expressão para IFN- $\gamma$ na pele e linfonodos de cerca de 50\% das cobaias infestadas três vezes (Tabs 2 e 3) com carrapatos e na pele de animais inoculados com saliva (Tab. 4)comparadas com os controles. 
Seria bom lembrar que os animais utilizados não eram isogênicos, fato que favorece aparecimento de variação individual. Possivelmente, se fosse aumentado o número de cobaias por grupo experimental obter-se-iam médias mais representativas, que quando comparadas às dos grupos controles indicariam uma diferença estatisticamente significativa.

Outra citocina de papel fundamental nas respostas mediadas por células é a IL-12. Fagócitos e células dendríticas são as maiores fontes de IL-12 no início do processo imune. Essa citocina possui atividade pró-inflamatória e sozinha é capaz de conduzir a polarização de células $\mathrm{T} \mathrm{CD}^{+}$naive em células com perfil Th1 produtoras de IFN- $\gamma($ TRINCHIERI, 2003).

Os resultados obtidos quanto à expressão de mensagem para IL-12p40 em cobaias infestadas três vezes apontaram para um aumento significativo da intensidade de mensagem para IL-12p40 nos linfonodos em comparação a cobaias controles e infestadas uma vez com carrapatos (Tab.3). A expressão de mRNA para IL12-p40 em cobaias re-infestadas coincide com o aumento da expressão de mensagem para IFN- $\gamma$, sugerindo a ativação de células T CD4 ${ }^{+}$ naive presentes nos linfonodos desses animais em células Th1 ativadas produtoras de IFN- $\gamma$.

Pertencente a um perfil Th2 de citocinas, a IL-5, juntamente com outras citocinas (IL-3 e GM-CSF), está envolvida na proliferação, diferenciação, maturação e migração de eosinófilos (LAMPINEN et al., 2004). De fato, outros pesquisadores mostraram que cobaias pré-sensibilizadas com 2, 4dinitrochlorobenzene e tratadas com IL-5 recombinante quando submetidas a um desafio desenvolveram eosinofilia transiente e acúmulo de eosinófilos no sítio do 
desafio (pele) (SATOH et al., 2000). Foi demonstrado ainda que camundongos transgênicos para IL-5 demonstram eosinofilia e infiltrado eosinofílico em muitos órgãos (TOMINAGA et al., 1991). Já com relação a carrapatos foi visto que cobaias infestadas têm aumento no número de eosinófilos no local de fixação dos carrapatos (SZABÓ \& BECHARA, 1999). Nossos resultados mostraram um aumento significativo na intensidade de mensagem para IL-5 nos linfonodos de cobaias infestadas uma vez com carrapatos comparados aos controles (Tab.3). A presença de IL-5, neste primeiro momento, pode estar desempenhando um papel quimiotático para eosinófilos.

O aumento de IL-5 observado também pode estar relacionado com a migração e acúmulo de basófilos no local de fixação dos carrapatos. De fato, diversos relatos têm demonstrado que existem muitas semelhanças entre basófilos e eosinófilos (HIRAl et al., 1997). Ambas as células possuem a maioria de suas estruturas de superfície em comum, incluindo receptores de quimiocinas e citocinas, e moléculas de adesão. Fatores hematopoiéticos, tais como IL-3, GMCSF e IL-5 atuam nos dois tipos celulares, e quimiocinas ligantes de CCR3 são capazes de induzir uma forte resposta de migração tanto para basófilos quanto eosinófilos (HIRAl et al., 1997).

Citocinas como IL-4 e IL-13 desempenham um importante papel na polarização de células $\mathrm{T} \mathrm{CD}^{+}$naive em células Th2 ativadas produtoras de citocinas que conduzem a resposta imune para um padrão humoral (MCKENZIE, 2000; KOBAYASHI et al , 2001). Dessa forma, a detecção de mensagem para IL-4 e IL-13 poderia determinar a participação ou não de respostas humorais na aquisição de resistência a carrapatos em cobaias. Observando os resultados 
obtidos na pele e linfonodos de animais infestados com carrapatos há ausência quase total de mensagem para IL-4 (Figs.1, 3, 5 e 7). Como esse é um padrão de resposta modulado também por IL-13, tentou-se analisar a produção dessa citocina, mas devido à inexistência da seqüência do gene para IL-13 no GeneBank não foi possível delinear primers para detecção de sua expressão.

Assim como IL-4, IL-13 e IL-5, a citocina IL-10 também pertence ao perfil de citocinas produzidas por células Th2. Seu papel regulatório nas respostas inflamatória e imune é bem conhecido e a produção de IL-10 é realizada por inúmeras células, sendo em grande parte por células Th2 ativadas e células T regulatórias (O'GARRA, et al 2004). Alguns trabalhos têm relatado que carrapatos induzem aumento de IL-10 em hospedeiros suscetíveis e isso poderia ter como conseqüência modulação da resposta imune do animal (WIKEL, 1996; KOPECKY et al., 1999; FERREIRA \& SILVA, 1999). Nossos resultados mostraram que cobaias, as quais são capazes de desenvolver resistência a infestações com carrapatos $R$. sanguineus, não apresentaram aumentada expressão de mensagem para IL-10 nos tecidos analisados (Figs. 1, 3, 5 e 7), reforçando a hipótese de que carrapatos não conseguem modular sua resposta eficientemente permitindo que seja montada uma resposta imune anti-carrapatos.

Como o processo de tricotomia e colagem das câmaras de alimentação no dorso de cobaias poderiam, por si só, desencadear a expressão de mRNA para algumas citocinas considerou-se relevante estudar o efeito da inoculação de saliva na expressão de citocinas. Para averiguar esse fato, inoculou-se saliva três vezes no dorso de cobaias e coletou-se pele e linfonodos em dois tempos diferentes (três e seis horas após a última inoculação). De forma inesperada, não foi 
detectada diferença significativa de intensidade de expressão para citocinas entre os grupos analisados Tabs. 4 e 5). Esse achado possivelmente pode ser explicado pelo fato de carrapatos durante infestações salivarem intermitentemente durante todo período de ingurgitamento (7-14 dias). Talvez para se reproduzir o efeito legítimo de uma infestação num animal, a saliva teria que ser inoculada continuamente ou ainda seria necessário variar sua composição, já que existem trabalhos que mostram que a saliva de carrapatos possui composição diferente dependendo do tempo de fixação dos carrapatos (WALKER \& FLETCHER, 1995).

De forma geral, portanto, os resultados indicam que infestações com carrapatos induzem um aumento significativo na intensidade de mensagem para IL-12p40 nos linfonodos e uma pequena elevação na intensidade de mRNA para IFN- $\gamma$ na pele e linfonodos de cobaias infestadas, assim como na pele de cobaias inoculadas com saliva. Esse padrão sugere que cobaias respondem a carrapatos com um perfil mais inclinado para Th1 que Th2.

Esses achados concordam com trabalhos que mostram que é possível conferir imunidade parcial em cães a carrapatos, imunizando-os com um extrato de intestino de carrapatos associado ao adjuvante completo de Freund, e não saponina (SZABÓ \& BECHARA, 1997). A maior eficiência da imunização com antígenos de carrapatos associados ao adjuvante completo de Freund provavelmente reside na capacidade desse adjuvante estimular preferencialmente a resposta imune do tipo Th1 (AUDIBERT \& LISE, 1993).

A resposta predominantemente Th1 demonstrada por cobaias infestadas com carrapatos pode prejudicar o ingurgitamento de ácaros ao conduzir a inflamação e influxo de células efetoras no local de fixação dos mesmos 
(TRAGER, 1939; RIBEIRO et al., 1985). Por outro lado, as citocinas pertencentes ao padrão Th1 também estão envolvidas no desenvolvimento de reações de DTH (KOBAYASHI et al., 2001) e tem sido demonstrado que cobaias resistentes, quando desafiadas com antígenos de carrapatos, desenvolvem uma pequena hipersensibilidade imediata e forte reação de DTH cutânea caracterizada pelo acúmulo de eosinófilos, basófilos e mononucleares (SZABÓ et al., 1995; SZABÓ \& BECHARA, 1999). Neste caso poderia ser sugerido que dada à presença de basófilos no local estaria sendo desenvolvida uma resposta de hipersensibilidade tardia de Jones-Mote, também conhecida como hipersensibilidade cutânea basofílica $(\mathrm{CBH})$. Esse tipo de hipersensibilidade tardia é caracterizada pela infiltração de células mononucleares e basófilos, e apresenta características de hipersensibilidade dos tipos imediato e tardio (GORMAN \& HALLIWELL, 1989).

O papel desempenhado por basófilos na resposta imune contra carrapatos ainda é desconhecido. Embora tenha sido sugerido que essas células participam de reações anafiláticas locais liberando mediadores farmacológicos que poderiam prejudicar o ingurgitamento de ácaros (PAINE et al., 1989). BROWN e colaboradores (1982) demonstraram que cobaias resistentes a carrapatos Amblyomma americanum tratadas com um soro anti-basófilo e anti-eosinófilo levou a eliminação da resistência, reforçando a participação destas células na expressão de resistência em cobaias.

Ainda que outros fatores possam estar envolvidos no desenvolvimento de resistência a ácaros, a caracterização de citocinas produzidas por animais resistentes (cobaias) poderá auxiliar o desenvolvimento de novas abordagens para o controle de carrapatos, como, por exemplo, sugerir adjuvantes mais 
adequados a serem utilizados em vacinas anti-carrapatos. O novo conhecimento gerado não se restringe à indução de proteção contra carrapatos, como também a possibilidade de aumentar a resistência de hospedeiros a patógenos transmitidos por carrapatos que poderiam ser controlados por uma resposta tipo Th1.

Por fim, este trabalho indica a necessidade de se desenvolverem pesquisas que identifiquem as células produtoras de IL-5, IFN- $\gamma$ e IL-12, assim como caracterizar o envolvimento de outras citocinas na aquisição de resistência, que não puderam ser examinadas pela falta de reagentes para a espécie animal utilizada. 


\section{CONCLUSÕES}

1. Cobaias infestadas uma vez com carrapatos mostraram um aumento significativo na intensidade de mensagem para IL-5 nos linfonodos comparadas aos controles.

2. Cobaias infestadas três vezes com carrapatos apresentaram um aumento significativo na intensidade de mensagem para IL-12p40 nos linfonodos.

3. Foi detectada expressão de mRNA para TGF- $\beta$ em todas as amostras analisadas (de animais experimentais e controles).

4. A expressão de mensagem para as citocinas IL-4 e IL-10 não foi detectada de maneira expressiva em nenhuma das amostras analisadas.

5. A inoculação de saliva de carrapatos não alterou o padrão de expressão de intensidade de nenhuma das citocinas analisadas. 


\section{REFERÊNCIAS BIBLIOGRÁFICAS}

ABBAS, A.; MURPHY, K.M.; SHER, A. - Functional diversity of helper T lymphocytes. Nature, 383:787-793, 1996.

ALLEN, J.R. - Immunology of interactions between ticks and laboratory animals. Exp. App. Acarol. 7:5-13, 1989.

ALLEN, J.R. - Tick resistance: basophils in skin reaction of resistant guinea pigs. Int. J. Parasitol., 3:195-200, 1973.

ALLEN, J.R., KHALIL H.M., WIKEL S.K. - Langerhans cells trap tick salivary gland antigens in tick-resistant guinea pigs. J. Immunol. 55(1):157-63,1979.

ANON. Pecuária bovina de corte: macro-análise sobre os principais problemas do setor. Depto. de Pesquisa e Desenvolvimento, Embrapa, 1997

ANON. Secretaria de Defesa Sanitária Animal do MA, Boletim de Defesa Sanitária Animal № Especial , $2^{a}$ edição. Prováveis prejuízos causados pelos carrapatos. Brasil, 1983.

ASKENASE, P.W; METZLER, C.M.; GERSHON, R.K. - Localization of leucocytes in sites of delayed-type hypersensitivity and in lymph nodes: dependence on vasoactive amines. Immunology. 1982 Oct;47(2):239-46.

AUDIBERT, F.M.; LISE, L.D. - Adjuvants: current status, clinical perspectives and future prospects. Immunol Today., Jun;14(6):281-4, 1993.

BALASHOV, Y.S. - Bloodsucking ticks (Ixodidae): vectors of disease in man and animals. Mis. Pub. Entomol. Soc. Am., 8: 161-166, 1972. 
BECHARA G.H., SZABO M.P., MACHADO R.Z., ROCHA U.F. - A technique for collecting saliva from the cattle-tick Boophilus microplus (Canestrini, 1887) using chemical stimulation. Environmental and temporal influences on secretion yield. Braz J Med Biol Res. 1988;21(3):479-84.

BECHARA, G.H.; SZABÓ, M.P.J.; FERREIRA, B.R.; GARCIA, M.V. Rhipicephalus sanguineus tick in Brazil: feeding and reproductive aspects under laboratorial conditions. Braz. J. Vet. Parasitol., 4:61-66, 1995.

BERGMAN, D.K.; RAMACHANDRA, R.N.; WIKEL, S.K. - Characterization of an immunosuppressant protein from Dermacentor andersoni (Acari: Ixodidae) salivary glands. J Med Entomol., Jul;35(4):505-9, 1998.

BERGMAN, D.K.; RAMACHANDRA, R.N.; WIKEL S.K. - Dermacentor andersoni: salivary gland protein suppresing T-lymphocyte responses to concanavalina A in vitro. Exp. Parasitol., 81(3):262-71, 1995.

BLISKA FM. - Prospecção de demandas tecnológicas na cadeia produtiva de carne bovina. Relatório preliminar. Campinas, 1997.

BROSSARD, M; MONNERON, J.P.; PAPATHEODOROU, V. - Progressive sensitization of circulating basophil against Ixodes ricinus L. antigens during repeated infestation of rabbits. Parasite Immunol., 4(5):335-61, 1982.

BROWN, S.J.; GALLI, J. S.; GLEICH, G. J AND ASKENASE, P.W. - Ablation of immunity to Amblyomma americanum by anti-basophil serum: cooperation between basophil and eosinophil in expression of immunity to ectoparasites (ticks) in guinea-pigs. J Immunol. 129 (2):790-796, 1982.

BROWN, S.J. - Highlights of contemporary reserch on host immune resistance to ticks. Vet. Parasitol., 28:321-334, 1988. 
CHABAUD, A.G. - L' infestation par des ixodinés provoque-t-elle une immunité chez I-hôte (2me note). Annales de Parasitologie 25 (5/6): 474-479, 1950.

CENTER FOR DISEASE CONTROL AND PREVENTION-Lyme Disease-United States, 1999. Morb. Mortal. Weekly Rep. 50(10): 181-185, 2001. Disponível em http://www.cdc.gov.

CHINERY, W.A.; AYITEY-SMITH, E. - Histamine blocking agent in the salivary gland homogenate of the tick Rhipicephalus sanguineus. Nature 265(5592):366-7, 1997.

DANAHAY, H.; BROADLEY, K.J.; MCCABE, P.J.; NIALS, A.T.; SANJAR, S. Temporal relationships between leukocytes, IL-5 and IL-8 in guinea pig lungs, plasma cortisol and airway function after antigen challenge. Inflamm Res., Jan;48(1):41-7, 1999.

ELVIN, C.M.; KEMP, D.H. - Generic approaches to obtaining efficacious antigens from vector arthropods. Int J Parasitol, 24: 67-79, 1994.

FERREIRA, B.R., SILVA, J.S. - Saliva of Rhipicephalus sanguineus tick impairs T cell proliferation and IFN-gamma-induced macrophage microbicidal activity. Vet Immunol Immunopathol 64:279-293, 1998.

FERREIRA, B.R., SILVA, J.S. - Successive tick infestations selectively promote a T helper 2 cytokine profile in mice. Immunology, 96:434-440, 1999.

FERREIRA, B.R., SZABO, M.J., CAVASSANI, K.A., BECHARA, G.H., SILVA, J.S. - Antigens from Rhipicephalus sanguineus ticks elicit potent cell-mediated immune responses in resistant but not in susceptible animals. Vet Parasitol., Jul 10;115(1):35-48, 2003. 
FOLHA DE SÃO PAULO, 2003. Disponível em http://www.folhauol.com.br

FOOD AND AGRICULTURE ORGANIZATION (FAO) - Yearbook Production, 1994. (Vol.48). Roma, 1995.

FREITAS, M.G.; COSTA, H.M.A.; COSTA, J.o; IIDE, P. - Entomologia e acarologia médica e veterinária. $6^{\mathrm{a}}$ ed. Belo Horizonte, Precis Ed. Gráfica, 1982. cap. 3, p. 35-32: Família Ixodidae.

FUKAO, T. \& KOYASU, S. - Expression of funcional IL-2 receptors on mature splenic dendritic cells. Eur. J. Immunol., 30(5):1453-1457, 2000.

GARIN, N.S.; GRABAREV, P.A. - [Immune reaction in rabbits and guinea pigs during repeated feeding on them of ixodid ticks Rhipicephalus sanguineus (Latreille., 1806)]. Med Parazitol (Mosk)., May-Jun;41(3):274-9, 1972.

GILLESPIE, R.D.; MBOW, M.L.; TITUS, R.G. - The immunomodulatory factors of bloodfeeding arthropod saliva. Parasite Immunol., 22(7):319-31, 2000.

GILLESPIE, R.D.; DOLAN, M.C.; PIESMAN, J.; TITUS, R.G. - Identification of an IL-2 binding protein in the saliva of the Lyme disease vector tick, Ixodes scapularis. J Immunol., Apr 1;166(7):4319-26, 2001.

GIRARDIN, P.; BROSSARD, M. - Effects of cyclosporin A on humoral immunity to ticks and on cutaneous immediate and delayed hypersensitivity reactions to Ixodes ricinus L. salivary-gland antigens in re-infested rabbits. Parasitol Res.;75(8):657-62, 1989.

GORMAN, N. T,; HALLIWELL, R.E.W. - Mechanisms of immunological injury in hipersensitivity reaction In: HALLIWELL, R. E. W.; GORMAN, N. T. Veterinary clinical immunology. London, W. B. Saunders., Ch. 11, p. 212-31, 1989. 
HIRAI, Y.; MIYAMASU, M.; TAKAISHI, T.; MORITA, Y. -Regulation of the fucion of eosinophils and basophils. Crit. Rev. Immunol. 17:325, 1997.

HOOGSTRAAL, H. ; KIM, K.C. - Tick and mammal coevolution, with emphasis on Haemaphysalis. In: KIM. K.C. (ed) Coevolution of parasitic arthropods and mammals. New York, Wiley-Interscience, 1985. cap. 10, p.505-568.

JITTAPALAPONG, S.; STICH, R.W.; GORDON, J.C.; BREMER, C.A.; BARRIGA, O.O. - Humoral immune response of dogs immunized with salivary gland, midgut, or repeated infestations with Rhipicephalus sanguineus. Ann $\mathbf{N}$ Y Acad Sci.;916:283-8, 2000.

KAUFMAN, W.R. - Tick-host interaction: A synthesis of current concepts. Parasitol Today., Feb;5(2):47-56, 1989.

KEMP, D.H.; BOURNE, A. - Boophilus microplus: the effect of histamine on the attachment of cattle-tick larvae-studies in vivo and in vitro. Parasitology., 80(3):487-96, 1980.

KLUNNER, T.; BARTELS, T.; VORDERMEIER, M.; BURGER, R.; SCHAFER, H. Immune reactions of CD4- and CD8-positive $T$ cell subpopulations in spleen and lymph nodes of guinea pigs after vaccination with Bacillus Calmette Guerin. Vaccine., Feb 28;19(15-16):1968-77, 2001.

KOBAYASHI, K.; KANEDA, K.; KASAMA, T. - Immunopathogenesis of delayedtype hypersensitivity. Microsc Res Tech. 2001 May 15;53(4):241-5.

KOPECKY, J.; KUTHEJLOVA, M. - Sppressive effect of Ixodes ricinus salivary gland extract on mechanisms of natural immunity in vitro. Parasite Immunol., 20(4):169-74, 1998. 
KUBES, M.; KOCAKOVA, P.; SLOVAK, M.; SLAVIKOVA, M.; FUCHSBERGER, N.; NUTTALL, P.A. - Heterogeneity in the effect of different ixodid tick species on human natural killer cell activity. Parasite Immunol., Jan;24(1):23-8, 2002

LAMPINEN M, CARLSON M, HAKANSSON LD, VENGE P.Cytokine-regulated accumulation of eosinophils in inflammatory disease. Allergy., Aug;59(8):793805, 2004.

LAWRIE, C.H.; RANDOLPH, S.E.; NUTTALL, P.A. - Ixodes ticks: serum species sensitivity of anticomplement activity. Exp. Parasitol., 93(4):207-14, 1999.

MACALUSO, K.R.; WIKEL, S.K. - Dermacentor andersoni: effects of repeated infestations on lymphocyte proliferation, cytokine production, and adhesionmolecule expression by BALB/C mice. Ann Trop Med Parasitol., Jun;95(4):413-27, 2001.

MCKENZIE, A.N. - Regulation of T helper type 2 cell immunity by interleukin- 4 and interleukin-13. Pharmacol Ther., Nov;88(2):143-51, 2000.

MATSUDA, H.; FUKUI, K.; KISO, Y.; KITAMURA, Y. - Inability of genetically mast cell-deficient $\mathrm{W} / \mathrm{Wv}$ mice to acquire resistance against larval Haemaphysalis longicornis ticks. J. Parasitol., 71(4):443-8, 1985.

MEJRI, N.; RUTTI, B.; BROSSARD, M. - Immunosuppressive effects of Ixodes ricinus tick saliva or salivary gland extracts on innate and acquired immune response of BALB/c mice. Parasitol Res.,Mar;88(3):192-7, 2002.

MOSMANN, T.R.; COFFMAN, R.L. - TH1 and TH2 cells: different patterns of lymphokine secretion lead to different functional properties. Annu Rev Immunol., 7:145-73, 1989. 
MOSMANN, T.R.; MOORE, K.W. - The role of IL-10 in crossregulation of T(H)1 and $T(H) 2$ responses. Parasitol Today., Mar;7(3):49-53, 1991.

MOSMANN, T.R.; SAD, S. - The expanding universe of T-cell subsets: Th1, Th2 and more. Immunol Today.,Mar;17(3):138-46, 1996.

MULENGA, A.; MACALUSO, K.R.; SIMSER, J.A.; AZAD, A.F. - The American dog tick, Dermacentor variabilis, encodes a functional histamine release factor homolog. Insect Biochem Mol Biol., Sep;33(9):911-9, 2003.

MUMCUOGLU, Y.Y.; FRISH, K.; SAROV, B.; MANOR, E.; GROSS, E.; GAT, Z.; GALUN, R. - Ecological studies on the brown dog tick Rhipicephalus sanguineus (Acari: Ixodidae) in Southern Israel and its relationship to Spotted Fever group Rickettsiae. Journal of Medical Entomology 30: 114-21, 1993.

NITHIUTHAI, S.; ALLEN, J.R. - Significant changes in epidermal Langerhans cells infested with ticks (Dermacentor andersoni). Immunology.,51(1):133-41, 1984a.

NITHIUTHAI, S.; ALLEN, J.R. - Effects of ultraviolet irradiation on epidermal Langerhans cells in guinea pigs. Immunology.,51(1):143-51, 1984b.

NITHIUTHAI, S.; ALLEN, J.R. - Langerhans cells present ticks antigens to lymph node cells from tick-sesitized guinea pigs. Immunology.,55(1):157-63, 1985.

NUTAL, P.A.; PAESEN, G.C.; LAWRIE, C.H.; WANG. H. - Vector-host interactions in disease trasnmission. J. Mol. Microbiol. Biotechnol., 2(4):3816, 2000.

O'GARRA, A.; VIEIRA, P.L.; VIEIRA, P.; GOLDFELD, A.E. - IL-10-producing and naturally occurring CD4+ Tregs: limiting collateral damage. J Clin Invest., Nov;114(10):1372-8, 2004. 
PAINE, S.H.; KEMP, D.H. - ALLEN J.R. - In vitro feeding of Dermacentor andersoni (Stiles): efects of histamine and other mediators. Parasitology.,86 (Pt 3):419-28, 1983.

PARKER, R.J.; WILSON, A.J. - The experimental transmission of Anaplasma marginale by the brown dog tick Rhipicephalus sanguineus in Australia. Aust Vet J 55., 606, 1979.

PEGRAM, R.G.; CLIFFORD, C.M.; WALKER, J.B.; KEIRANS, J.E. - Clarification of the Rhipicephalus sanguineus group (Acari; Ixodoidea, Ixodidae). I. R. sulcatus (Neuman, 1908) and R. turanicus (Pomerantsev, 1936). Systematic Parasitology 10: 3-26, 1987.

PÉTER, O.; BURGDORFER, W.; AESCHLIMANN, A.; CHATELANAT, P. Rickettsia conorii isolated from Rhipicephalus sanguineus introduced into Switzerland on a pet dog. Zeitschrift für Parasitenkunde 70: 265-270, 1984.

RAMACHANDRA, R.N.; WIKEL, S.K. - Modulation of host-immune responses by ticks (Acari: Ixodidae): effect of salivary gland extracts on host macrophages and lymphocyte cytokine production. J Med Entomol., Sep;29(5):818-26, 1992.

RAMACHANDRA, R.N.; WIKEL, S.K. - Effects of Dermacentor andersoni (Acari: Ixodidae) salivary gland extracts on Bos indicus and $B$. taurus lymphocytes and macrophages: in vitro cytokine elaboration and lymphocyte blastogenesis. J Med Entomol., May;32(3):338-45, 1995.

RIBEIRO, J.M.C.; MAKOUL, G.T.; LEVINE, J.; ROBINSON, D.R.; SPIELMAN, A. Antihemostatic, anti-inflammatory and immunosuppressive properties of the saliva of a tick, Ixodes dammini. J. Exp. Med., 161:332-344, 1985. 
RIBEIRO, J.M.; SPIELMAN, A. - Ixodes dammini: salivary anaphylatoxin inactivating activity. Exp Parasitol., Oct;62(2):292-7, 1986.

RIBEIRO, J.M. - Ixodes dammini: salivary anti-complement activity. Exp. Appl. Acarol., 7(1):15-20, 1987.

RIBEIRO, J.M. - Vector saliva and its role in parasite transmission. Exp Parasitol., Jul;69(1):104-6, 1989.

RIBEIRO, J.M.; WEIS, J.J.; TELFORD SR 3RD. - Saliva of the tick Ixodes dammini inhibits neutrophil function. Exp Parasitol., May;70(4):382-8, 1990.

ROTTMAN, J.B.; TOMPKINS, W.A.; TOMPKINS, M.B. - A reverse transcriptionquantitative competitive polymerase chain reaction (RT-qcPCR) technique to measure cytokine gene expression in domestic mammals. Vet Pathol., Mar;33(2):242-8, 1996.

SAMBROOK, J.; FRITSH, E.F. \& MANIATIS, T.- Molecular cloning. A laboratory manual. Cold Spring Harbor Laboratory, N.Y., 1989.

SATOH, T.; YOKOZEKI, H.; NISHIOKA, K. - Pathogenic roles of eosinophils in guinea-pig contact sensitivity: regulation of dermal eosinophilia with remotely administered IL-5. Clin Exp Immunol., Dec;122(3):300-7, 2000.

SCAROZZA, A.M.; RAMSINGH, A.I.; WICHER, V.; WICHER, K. - Spontaneous cytokine gene expression in normal guinea pig blood and tissues. Cytokine., Nov;10(11):851-9, 1998.

SHER, A.; COFFMAN, R.L. - Regulation of immunity to parasites by T cells and T cell-derived cytokines. Ann. Rev. Immunol., 10:385-409, 1992. 
SIGAL, L.M. - Lyme disease: A review of aspects of its immunology and immunopathogenesis. Annu. Rev. Immunol., 15:63-92, 1997.

SIMPSON, R.M.; GAUNT, S.D.; HAIR, J.A.; KOCAN, K.M., HENK, W.G.; CASEY, H.W. - Evaluation of Rhipicephalus sanguineus as potential vector of Ehrlichia platys. Amer J Vet Res 52: 1537-1541, 1991.

STEPHEN, I.C.; ACHYUTHARAO, K.N. - Natural occurence of Coxiella burnetii in the brown dog tick Rhipicephalus sanguineus. Indian J Medical Res 71: 865869, 1980.

SZABÓ, M.P.J.; BECHARA, G.H. - Immunisation of dogs and guinea pigs against Rhipicephalus sanguineus ticks using gut extract. Vet. Parasitol., 68:283-294, 1997

SZABÓ, M.P.J.; MUKAI, L.S.; ROSA, P.C.S. BECHARA, G.H. - Differences in the acquired resistance of dogs, hamsters, and guinea pigs to repeated infestations with adult ticks Rhipicephalus sanguineus (Acari:Ixodidae). Braz. J. Vet. Res. Anim. Sci., 32:43-50, 1995.

SZABÓ, M.P.; BECHARA, G.H. - Sequential histopathology at the Rhipicephalus sanguineus tick feeding site on dogs and guinea pigs. Exp Appl Acarol., Nov;23(11):915-28, 1999.

SZABO, M.P.; AOKI, V.L.; SANCHES, F.P.; AQUINO, L.P.; GARCIA, M.V.; MACHADO, R.Z.; BECHARA, G.H. - Antibody and blood leukocyte response in Rhipicephalus sanguineus (Latreille, 1806) tick-infested dogs and guinea pigs. Vet Parasitol., Jul 10;115(1):49-59, 2003. 
SRIVASTAVA, S.C.; VARMA, M.G.R. - The culture of tick Rhipicephalus sanguineus (Latreille) (Ixodidae) in the laboratory. J. Med. Entomol., 1:154157,1964 .

TATCHELL, R.J. - Interactions between ticks and their hosts. Int J Parasitol 17: 597-606, 1987.

TOMINAGA, A.; TAKAKI, S.; KOYAMA, N.; KATOH, S.; MATSUMOTO, R.; MIGITA, M.; HITOSHI, Y.; HOSOYA, Y.; YAMAUCHI, S.; KANAI, Y.; ET $A L$.Transgenic mice expressing a $B$ cell growth and differentiation factor gene (interleukin 5) develop eosinophilia and autoantibody production. J Exp Med., Feb 1;173(2):429-37, 1991.

TRINCHIERI, G. - Interleukin-12 and the regulation of innate resistance and adaptive immunity. Nat Rev Immunol. 2003 Feb;3(2):133-46.

THEIS, J.H.; BUDWISER, P.D. Rhipicephalus sanguineus: sequential histopathology at the host-arthropode interface. Experimental Parasitology, v.36, p.77-105, 1974.

TRAGER, W. (1939) Acquired immunity to ticks. J Parasitol 25: 57-81.

VALENZUELA, J.G.; CHARLAB, R.; MATHER, T.N.; RIBEIRO, J.M. - Purification, cloning and expression of a novel salivary anticomplement protein from the tick, Ixodes scapularis. J. Biol. Chem., 275(25):18717-23, 2000.

WALKER, A.R.; FLETCHER, J.D., GILL, H.S. - Structural and histochemical changes in the salivary glands of Rhipicephalus appendiculatus during feeding. Int J Parasitol., Feb;15(1):81-100, 1985. 
WANG, H.; NUTTALL, P.A. - Immunoglobulin-binding protein in ticks: new target for vaccine development against a blood-feeding parasite. Cell Mol. Life Sci., 56(3-4):286-95, 1999.

WIKEL, S.K.;ALLEN, J.R. - Acquired resistance to ticks. II. Effects of Cyclophosphamide on resistance. Immunology. 1976 Apr;30(4):479-84.

WIKEL, S.K. - Host immunity to ticks. Ann Rev Entomol 41:1-22, .1996.

WIKEL, SK. - Tick modulation of host cytokines. Exp Parasitol., Nov;84(2):304-9, 1996. 